\title{
A fish fauna from the lowermost Bartonian of the Transylvanian Basin, Romania
}

\author{
Nicolae Trif, Vlad Codrea, and Viorel Arghiuș
}

\begin{abstract}
A fish fauna newly discovered in the middle Eocene marine sediments cropping out near the village of Luna de Sus, Romania, completes the fossil record of the Eastern European region. Teeth belonging to 15 species of Chondrichthyes and two species of Actinopterygii are herein recorded from the lowermost Bartonian deposits. These Paleogene fish document a marine tropical environment of medium deep waters in the northwestern area of the Transylvanian Basin. The vertical distributions of extant equivalent taxa allow a sea depth estimation of 100 to $200 \mathrm{~m}$. The warm climate is documented by both the present faunal assemblage and previous palynological studies. It is important to note the presence of the scarcely known and poorly understood pycnodont species Phacodus punctatus and of the oldest representative of Labridae from this Carpathian area. The diversity of the fauna was found to be average compared to some areas from Western Europe or North Africa, but it falls within the regional diversity range of the Eastern European localities.
\end{abstract}

Nicolae Trif. Department of Geology, Faculty of Biology-Geology, Babeş-Bolyai University, 1 Kogălniceanu St., 400084, Cluj-Napoca, Romania and Brukenthal National Museum, Natural History Museum, Sibiu, Romania, 1 Cetății St., Sibiu, 550160, Romania. nicolae.trif@gmail.com

Vlad Codrea. Department of Geology, Faculty of Biology-Geology, Babeş-Bolyai University, 1

Kogălniceanu St., 400084, Cluj-Napoca, Romania. vlad.codrea@ubbcluj.ro

Viorel Arghiuș. Environmental Sciences Department, Faculty of Environmental Sciences and Engineering, Babeş-Bolyai University, 30 Fântânele St., 400294, Cluj-Napoca, Romania. arghius.viorel@ubbcluj.ro

Keywords: sharks; bony fish; Eocene; Căpuș Formation; Tethys Sea

Submission: 29 July 2018. Acceptance: 12 August. 2019.

Trif, Nicolae, Codrea, Vlad, and Arghiuș, Viorel. 2019. A fish fauna from the lowermost Bartonian of the Transylvanian Basin, Romania. Palaeontologia Electronica 22.3.56. 1-29. https://doi.org/10.26879/909

palaeo-electronica.org/content/2019/2709-bartonian-fish-from-transylvania

Copyright: September 2019 Paleontological Society.

This is an open access article distributed under the terms of Attribution-NonCommercial-ShareAlike 4.0 International (CC BY-NC-SA 4.0 ), which permits users to copy and redistribute the material in any medium or format, provided it is not used for commercial purposes and the original author and source are credited, with indications if any changes are made.

creativecommons.org/licenses/by-nc-sa/4.0/ 


\section{INTRODUCTION}

Eocene-age fish teeth in the Transylvanian Basin were first described in the 1850 s by Neugeboren $(1850,1851)$, who listed material belonging to 65 species of sharks from the southern side of this sedimentary basin. Almost half a century later, Koch (1894) reported a few new occurrences of Eocene fish teeth (again, mostly sharks) originating from the northwestern side of the basin. It is likely that in Koch's list, both middle and upper Eocene strata were represented, but the actual stratigraphy could not be confidently determined from this work. This same author appended these data to a larger subsequent list that includes the former AustroHungarian Empire (Koch, 1900). Following these researchers, only a handful of geologists focused on this topic, surveying mostly the northwestern area of the basin. The first one was Fuchs (1963, 1966), who described some fragmentary Myliobatis teeth from the Priabonian of Cluj-Napoca surroundings. The diversity of the Eocene fish fauna only started to be revealed a couple of decades later (Șuraru et al., 1980; Șuraru and Șuraru, 1987), but these studies focused exclusively on the same geological age. The list of Priabonian species has been supplemented again in the final decade of the last century (Dica et al., 1996; Codrea et al., 1997). The first definite mention of the middle Eocene fish fauna was at the beginning of the twenty-first century in an unpublished Ph.D. thesis (Dica, 2006). From the type locality of the Căpuș Formation
(Căpușul Mic), Jaekelotodus sp., Striatolamia macrota (Agassiz, 1843), Myliobatis sp., Aetobatus irregularis (Agassiz, 1843) and Pycnodontidae indet. have been illustrated and described.

Recent surveys of the middle Eocene deposits of the Luna de Sus locality revealed a rich assemblage of fish teeth, a rostral and a dermal spine, and a tail sting. Luna de Sus is situated on the northwestern side of the Paleogene Transylvanian Basin, central Romania, at about $10 \mathrm{~km}$ westward from the city of Cluj-Napoca (Figure 1). This paper is the first to describe this locality for fossil fishes in Romania.

\section{GEOLOGICAL SETTING}

According to the paleogeographic reconstructions of the Tethys Sea (Meulenkamp and Sissingh, 2003), during the late Lutetian, the northwestern area of the recent Transylvanian Depression was part of a Paleogene sedimentary basin covered by a shallow sea spreading over the thrusting nappes of the Apuseni Mountains landmass. To the east, this sea was in connection with the Eastern Carpathians Paleogene Flysh trough (i.e., the outer "Moldavides", sensu Săndulescu, 1984). The Căpuş Formation (Popescu, 1978) of middle Eocene age is exposed in the northwestern area of the Transylvanian Basin (Gilău sedimentary area; Rusu, 1987).

The sedimentology illustrates a paleoenvironment of an inner continental shelf of an open sea

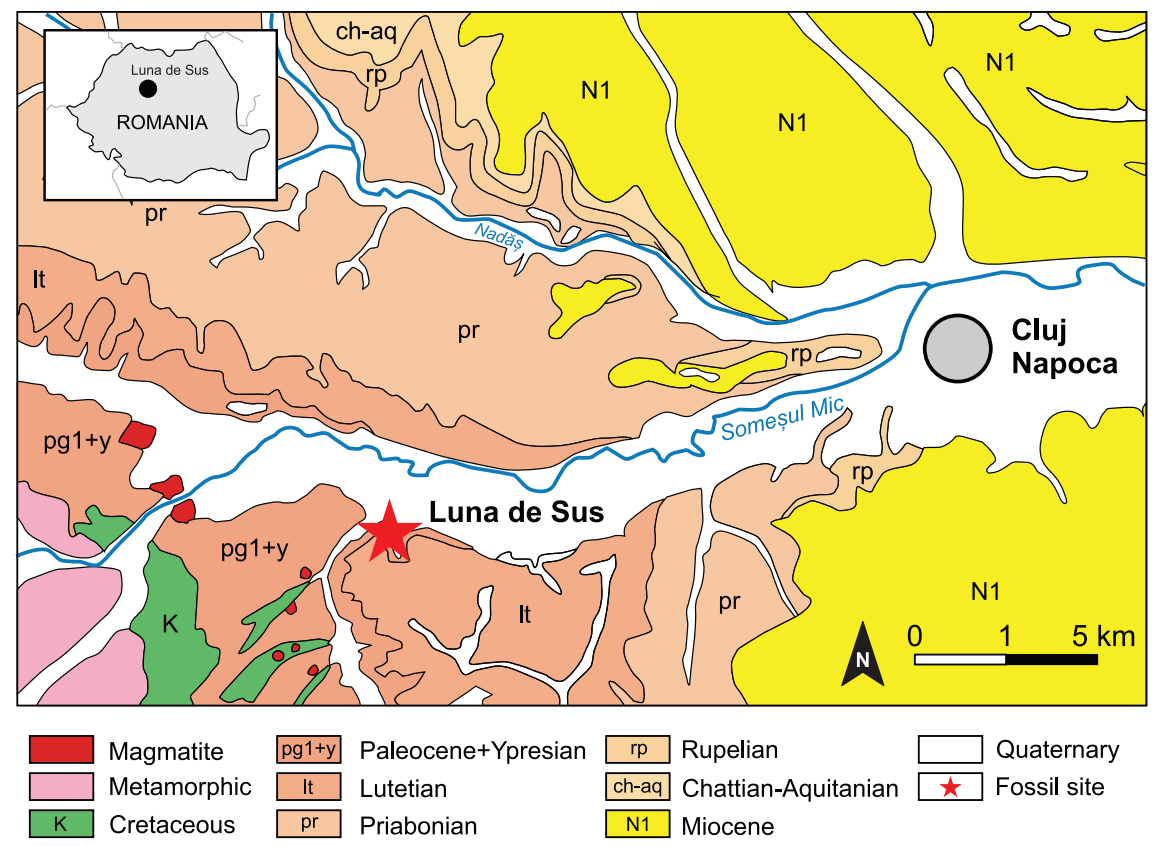

FIGURE 1. Location of the Luna de Sus study site (after the Geological Map of Romania, 1:200.000 folio Cluj, simplified and modified). 




FIGURE 2. Lithostratigraphy of the studied outcrop. 1, Lithostratigraphic log of the Eocene deposits from the Gilău sedimentary area (modified and simplified after Rusu et al., 2014). 2, Lithostratigraphic log at Luna de Sus.

with a tidal regime (Rusu et al., 2004). The formation consists mainly of marls bearing several important mollusk biohorizons with regional distributions useful for correlating these deposits. Its basal segment represents the level with Pycnodonte brogniartii Bronn, 1831, while the top bears the level with Nummulites perforatus Montfort, 1808 (Figure 2.1). The latest geological study shows that the age of the formation is Lutetian-Bartonian, but only its basal portion is Lutetian, with the remaining portion belonging to the Bartonian (Rusu et al., 2004).

The outcrop is situated on a very steep ravine, a right tributary of the Feneș Creek, on the southern side of the village of Luna de Sus. Its left bank is covered by a landslide; therefore, the main interest is restricted to only a few meters on the right bank of the ravine. The nearest equivalent outcrops situated at $650 \mathrm{~m}$ south-west, $400 \mathrm{~m}$ east and $80 \mathrm{~m}$ north of the gully did not reveal any fish fauna.

The Luna de Sus lithostratigraphic log is over $10 \mathrm{~m}$ thick, including: $7 \mathrm{~m}$ of marls bearing a basal
Pycnodonte brongniarti lumachelle; $0.1 \mathrm{~m}$ marl with Sokolovia eszterhazyi Pávay, 1871, lumachelle; $0.17 \mathrm{~m}$ calcareous sandstone with some microconglomerate elements. The last two layers are where the fish remains were found. Above these layers there is a very thin $(0.07 \mathrm{~m})$ layer of quartz microconglomerate followed by $1 \mathrm{~m}$ of clayey shale and $2.4 \mathrm{~m}$ of marls bearing lumachelle of Nummulites perforatus. The outcrop exposes rocks of a geological age very close to the lowermost Bartonian, just above the Lutetian/Bartonian boundary (Figure 2.2).

\section{MATERIAL AND METHODS}

The specimens were collected during 20 short field excursions, from March 2009 to September 2017. The photographs were taken with a Nikon D80 camera mounted on a Nikon SMZ 1000 binocular microscope and with a Nikon D700 camera and a $105 \mathrm{~mm}$ Sigma lens. The described material is stored at the Faculty of Environmental Science and Engineering, Babeș-Bolyai University, Cluj Napoca, Romania (abbreviated hereinafter, FES). 
The single exception is the VT459 specimen donated to the Babeş-Bolyai University Paleontology-Stratigraphy Museum in Cluj Napoca (abbreviated hereinafter, BBUPSM). The taxonomic identification of the described material included a comparison with the high-resolution images of the holotype and paratypes of Macrorhizodus nolfi Zhelezko, 1999, from the Darwin State Museum, Moscow (DSM) and of the holotype of Phacodus punctatus Dixon, 1850, from the Natural History Museum, London (NHM). The systematic paleontology part follows Cappetta (2012) and Last et al. (2016a). The use of the name Otodus Agassiz, 1843, follows Cappetta (2012), and it includes Carcharocles as a subgenus. The terminology follows Deynat (1998), Cappetta (2012) and Hovestadt and Hovestadt-Euler (2013).

During the field excursions about $175 \mathrm{~kg}$ of sediment (sandstone) was collected. The high iron content of the sandstone made it somewhat inert to the acetic acid reaction that was used to dissolve the rock. Therefore, the process of disaggregation has been tedious and time consuming. A $0.5 \mathrm{~mm}$ mesh sieve was used to sieve the resulting sediment. The disaggregation of the sandstone samples together with the direct field collecting yielded ca. 75 fish teeth, rostral and dermal spines and a tail sting.

\section{SYSTEMATIC PALEONTOLOGY}

Class CHONDRICHTHYES Huxley, 1880

Subclass ELASMOBRANCHII Bonaparte, 1838

Order HETERODONTIFORMES Berg, 1937

Family HETERODONTIDAE Gray, 1851

Genus HETERODONTUS Blainville, 1816

Heterodontus sp.

Figure 3.1-7

Material. Two teeth (FES 045 and 098).

Description. Both teeth are small. Only the specimen FES 045 is complete, with a length and width of 8.1 by $3.2 \mathrm{~mm}$. The teeth are labio-lingually compressed and mesio-distally elongated. A reticulated ornamentation is present on the labial side. The reticulation becomes smaller and finer towards the labial edge. The lingual face has an ornamentation of weak parallel ridges perpendicular to the mesial-distal direction. A longitudinal main ridge is present on the same direction, interrupted by a large central bump (in FES 098), or by a central massive functional wear facet (in FES 045). In occlusal view, the specimen FES 045 has a general sigmoid shape, with a rounded end in the mesial direction and an angled, pointed one distally. The crown overhangs the root in all directions.
The root is low and flat. We cannot observe any marginal lingual or labial foramina because of some strongly cemented sediment adherent to the root.

Remarks. There are several Eocene species of Heterodontus: H. pineti Case, 1981 (Priabonian, Georgia, USA), H. vincenti Leriche, 1905 (Lutetian, Belgium) and $H$. wardenesis Casier, 1966 (Ypresian, England). Unfortunately, the preservation status of the fossils at our disposal does not allow us an assignation below the genus level.

Order CARCHARHINIFORMES Compagno, 1977

Family CARCHARHINIDAE Jordan and Evermann, 1896

Subfamily CARCHARININAE Jordan and Evermann, 1896

Genus RHIZOPRIONODON Whitley, 1929

Rhizoprionodon ganntourensis Arambourg, 1952

Figure 3.8-11

Material. Two teeth (FES 076 and 082).

Description. The teeth are small, their height around $2.5 \mathrm{~mm}$ and their width of almost $4 \mathrm{~mm}$. The cusp is strongly bent distally. No cusplets are present, but the tooth exposes a distinct distal heel. The mesial side is elongated and slightly convex. The labial base of the enamel is quasi rectilinear, while on the lingual side it is slightly arched. The root foramen is small, oval and shifted distally.

Remarks. The teeth of this genus are characterized by a distinct gynadric heterodonty (Cappetta, 2012). In males, the central part of the cusp is thicker, and the mesial cutting edge is less convex. Our specimens are strongly compressed in the labial-lingual direction, and the central part of the cusp is strongly bent towards the rear. We interpret our specimens as belonging to females. According to Cappetta (1987), the teeth of this genus are very similar to the ones found in the Scoliodon and Loxodon genera. No progress has been made so far in the last quarter century to settle this issue, and the data remain the same in the more recent works (Cappetta, 2012).

Only a single Eocene species is known, Rhizoprionodon ganntourensis. The species is also present in the middle Eocene (Lutetian) of Morocco (Arambourg, 1952), Uzbekistan (Case et al., 1996), Togo (Cappetta and Traverse, 1988), the upper Eocene of France (Cappetta and Nolf, 1981), as well as the Eocene (Ciobanu, 2002) and the upper Eocene (Priabonian) of Romania (Dica, 2006).

Subfamily GALEOCERDINAE Whitley, 1929 Genus GALEOCERDO Müller and Henle, 1838 


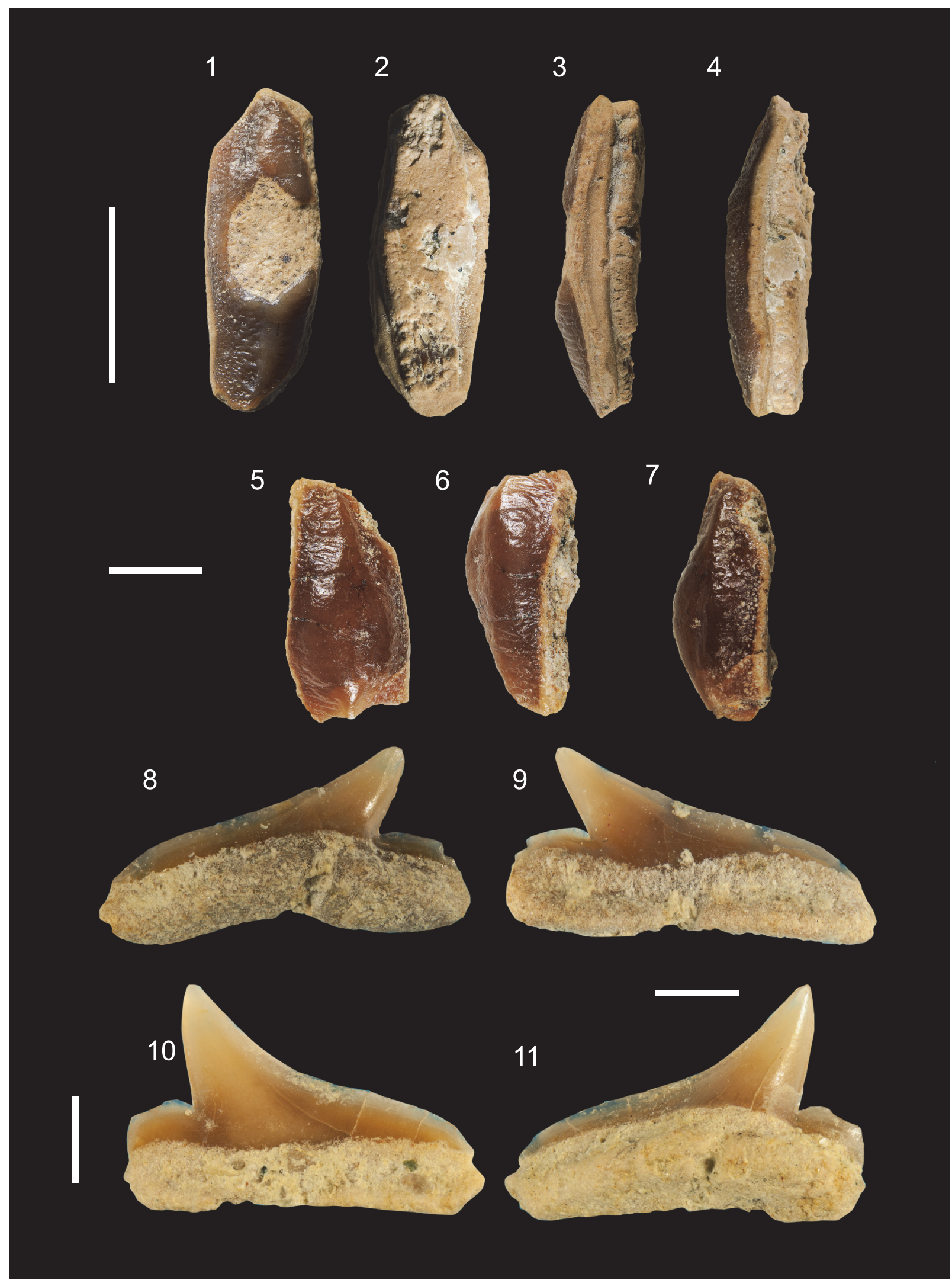

FIGURE 3. Fish fossils from Luna de Sus. 1-4, Heterodontus sp., (FES 045). 5-7, (FES 098); 8-9, Rhizoprionodon ganntourensis, (FES 076). 10-11, (FES 082). 1, 5, occlusal views. 2, basal view. 3, 6, 8, 11, lingual views. 4, 7, 9, 10, labial views. Scale bars equal 1-7 (5 mm), 8-11 (1 mm). 

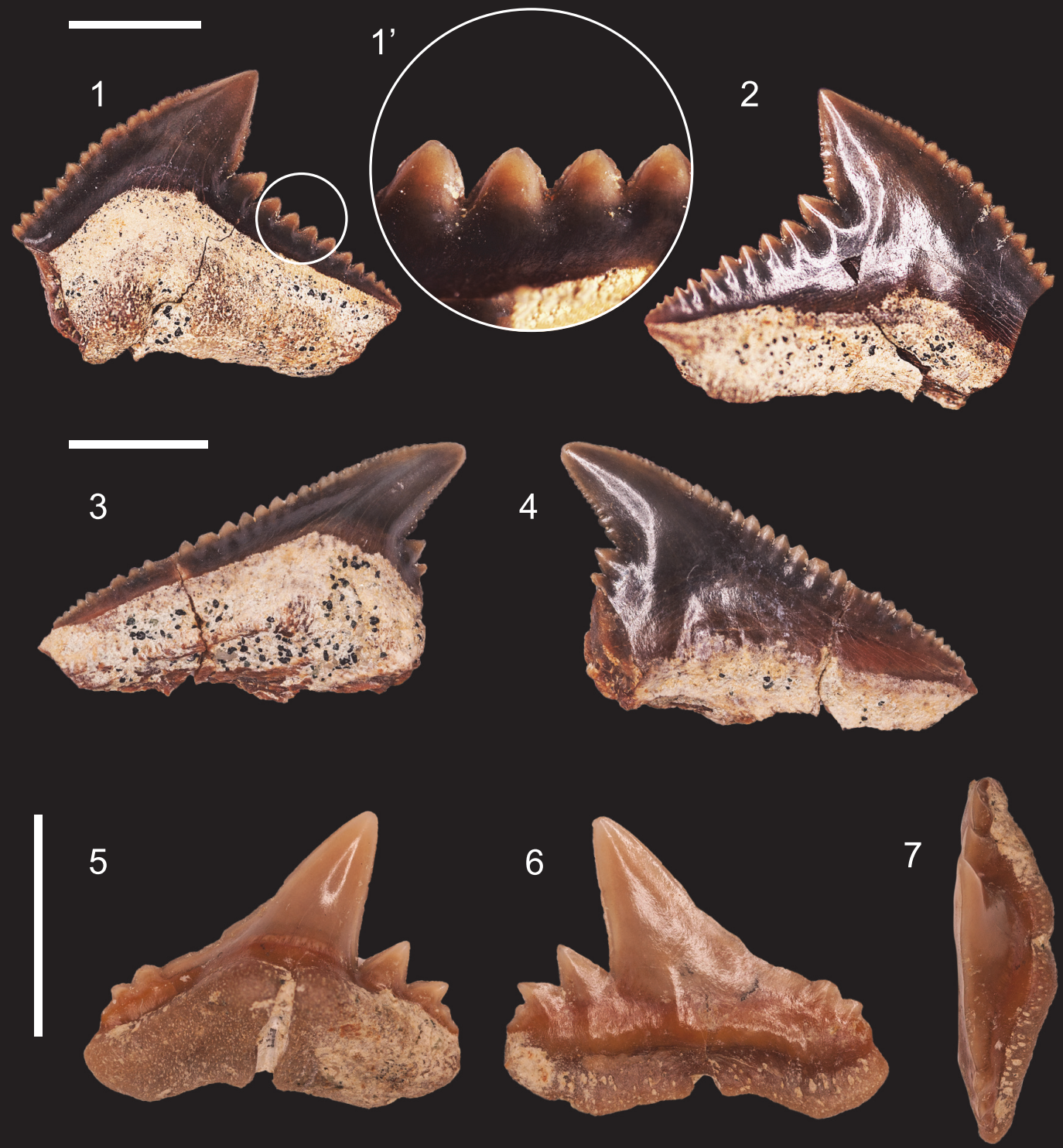

8

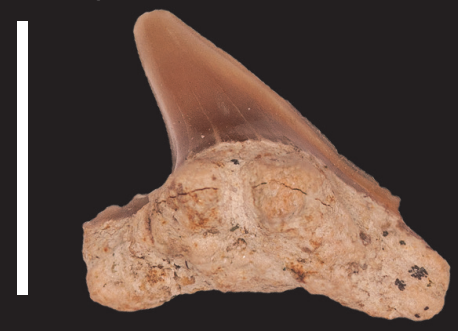

9

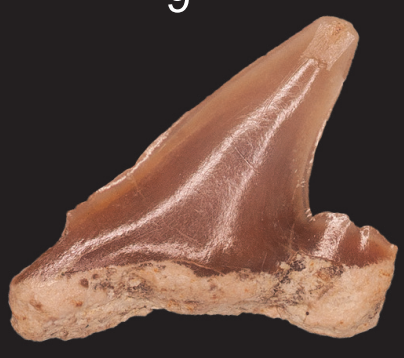

10
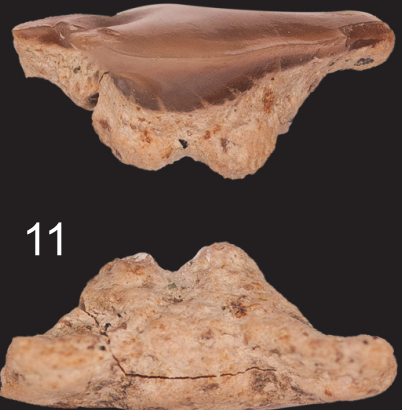

FIGURE 4. Fish fossils from Luna de Sus. 1-2, Galeocerdo cf. eaglesomei, (FES 043). 3-4, (FES 044). 5-7, Physogaleus secundus, (FES 050). 8-11, (FES 053). 1, 3, 5, 8, lingual views. 2, 4, 6, 9, labial views. 7, 10, apical views. 11, basal view. 1', detail of serration. Scale bars equal $5 \mathrm{~mm}$. 


\section{Galeocerdo cf. eaglesomei White, 1955}

Figure 4.1-4

Material. Two incomplete teeth (FES 043 and 044).

Description. The teeth are broad but also high, with a triangular crown that bears a central distinct cusp inclined distally. FES 043 is $15 \mathrm{~mm}$ wide and $12 \mathrm{~mm}$ tall, while FES 044 is $15 \mathrm{~mm}$ wide and 10 $\mathrm{mm}$ tall. The mesial cutting edge is slightly convex in one specimen and completely straight in the other one, and it has numerous serrations that get smaller towards the apex of the crown. The distal cutting edge is almost straight, with serrations increasing towards the middle. No nutritive groove can be observed on the lingual surface of the root, but this could be due to its poor state of preservation. Both mesial and distal cutting edges of the main cusp are irregularly serrated. The serration of the main cusp covers two thirds of its length. The root is only partially preserved on both specimens. Specimen FES 044 probably had a very lateral position towards the commissure. It is interesting to note the possible formation of a possible secondary serration in specimen FES 043 (Figure 4.1').

Remarks. At least three Eocene species of Galeocerdo are known from the Eocene: $G$. latidens Agassiz, 1843, G. aegyptiacus Stromer, 1905 and G. eaglesomei White, 1955. Another possible species, named Galeocerdo sp., from the Fayoum Depression of Egypt, has also been described (Case and Cappetta, 1990).

We found Galeocerdo eaglesomei to be the species most similar to our material, with a comparable serration that extends closer to the tip of the cusp. The tall root is a morphological element also found in our material. The size of the tooth and the presence of the serration on the main cusp differentiate our fossils from the species G. latidens. Galeocerdo aegyptiacus from the Eocene of the Fayoum Depression (Egypt) differs from our material in being smaller in the basal-apical direction and with a more convex mesial edge. Galeocerdo $\mathrm{sp}$. is similar to our specimens, but it has a smaller serration on the lateral heels. This unnamed species is considered to be distinct from G. latidens, $G$. eaglesomei and G. aegyptiacus (Underwood et al., 2011). Due to the fragmentary status of the fossils we have at our disposal, we keep our assignment to Galeocerdo cf. eaglesomei.

The species Galeocerdo eaglesomei can also be encountered in the middle Eocene of Texas (Westgate, 1989), Alabama (Maisch et al., 2014), the upper Eocene of Mexico (Gonzales Barba,
2003), the Eocene of Nigeria (White, 1955) and Egypt (Underwood et al., 2011).

Ciobanu (2002) documented Galeocerdo (as G. latidens) from the Eocene of Turnu Roșu, Romania.

\author{
Incertae subfamiliae \\ Genus PHYSOGALEUS Cappetta, 1980 \\ Physogaleus secundus Winkler, 1876
}

Figure 4.5-11

Material. Three lateral teeth (FES 050, 051, 052) and one antero-lateral tooth (FES053).

Description. The lateral teeth measure only 6 to 8 $\mathrm{mm}$ mesio-distally and 4 to $5 \mathrm{~mm}$ in the apicalbasal direction. The main cusp is inclined distally and has a triangular shape. The mesial side of each tooth is long, almost straight, slightly convex with two very irregular cusplets. The distal edge is shorter and continues with two strong and triangular cusplets that are bent distally more than the main cusp. The teeth are labio-lingually compressed. On the lingual face the enameloid covers about half of the root height and forms a straight crown-root contact, while on the labial side the contact has an arched shape. The lingual side of the root has a deep central furrow while the labial side has only some dispersed foramens.

The antero-lateral tooth measures $6.5 \mathrm{~mm}$ mesio-distally and $5.5 \mathrm{~mm}$ in the apical-basal direction. The main cusp is narrower than that of the lateral teeth. The mesial edge is straight but incomplete at its base. The distal edge is shorter than the mesial one but the distal cusplets are smaller and not as well outlined as they are in the lateral teeth. The root has a much more pronounced lingual protuberance than that of the lateral teeth and the central furrow is very deep.

Remarks. Four Eocene species of Physogaleus are known: $P$. tertius Winkler, $1874, P$. latecuspidatus Müller, 1992, $P$. secundus Winkler, 1876 and $P$. americanus Case, 1994. The species $P$. latecuspidatus is easily differentiated from $P$. secundus by a wider main cusp, especially towards the tip of the crown, hence its very illustrative name. Physogaleus americanus is a much smaller species with teeth of around $3.0 \mathrm{~mm}$ and with a distinct cusp on the mesial side. Physogaleus tertius lacks cusplets in the lateral teeth; it only has a wavy lateral edge that Case (1994 p. 121) considered an "unerupted ridge". We acknowledge another poorly known species, P. rosehillensis Case and Borodin, 2000, described from a single tooth. Taking into account the limited description and the poor material, we will not consider $P$. rosehillensis further, as it lacks sufficient differentiating characters. 
The morphology of our specimens is very similar to one of the specimens figured by Cappetta (2012, fig. 297), except for the labio-lingual compression, which is more pronounced in our teeth. We feel confident to assign our specimens to Physogaleus secundus.

Physogaleus secundus is common in the Eocene of Europe and Africa. The species is also found in the lower-middle Eocene of Denmark (Carlsen and Cuny, 2014), the Lutetian of Belgium (Eckhaut and De Schutter, 2009), the Ypresian of Morocco (Noubhani and Cappetta, 1997) and the Eocene of Romania (Ciobanu, 2002; Dica, 2006).

Genus ABDOUNIA Cappetta, 1980

Abdounia sp.

Figure 5.12-13

Material. One anterior (FES 056) and one lateral tooth (FES 057).

Description. The teeth measure only $7.4 \mathrm{~mm}$ (FES 057) and $4.5 \mathrm{~mm}$ (FES 056) high in the apical-basal direction. The main cusp is triangular with a straight contact between the crown and the root on the labial side. The lingual side is convex. The lateral tooth has some very faint folds at the base of the crown, on the labial side. The cusplets on both teeth are triangular, divergent and not separated by the crown on the labial side.

Remarks. Based on the described morphology we assign our material to Abdounia sp. as it resembles closely the description of the genus in Cappetta (2012, p. 308). The scarce material and the imperfect preservation of the specimens prevent us from assigning a species. The genus Abdounia is common in the Eocene of Africa, Europe and Americas with at least seven valid species.

Order LAMNIFORMES Berg, 1958

Family LAMNIDAE Müller and Henle, 1838

Genus MACRORHIZODUS Glikman, 1964

Macrorhizodus praecursor (Leriche, 1905)

Figure 5.1-4

Material. Two teeth (FES no 041 and 042).

Description. The morphology of the specimens indicates a lateral position. The specimen FES 041 is $49 \mathrm{~mm}$ high and $49 \mathrm{~mm}$ wide while specimen FES 040 is $40 \mathrm{~mm}$ high and $41 \mathrm{~mm}$ wide. Both teeth have a triangular crown that is inclined slightly distally. The base of the crown is continued by a heel on both sides. The heels are raised on both sides of the tooth forming an almost straight cusplet. The contact of the crown with the root follows a straight line. The root lobes are slightly asymmetrical; the distal lobe has a sub-rectangular outline, and the mesial lobe is pointed and a little bit elongated. The specimen FES 041 has a visible central foramen on the lingual face of the root.

Remarks. Two species and a subspecies of Macrorhizodus are presumed to be present in the Eocene: M. praecursor (Leriche, 1905), M. praecursor americanus (Leriche, 1942) and M. nolfi Zhelezko in Zhelezko and Kozlov, 1999. The differences are based on the outline of the crown, the outline of the root lobes and the presence of socalled heel bumps (or vestigial cusplets), respectively.

Malyshkina and Ward (2016) consider that the presence of high lateral cusplets (or heels) separates the species Macrorhizodus nolfi from $M$. praecursor, but they note that the characteristics that separate the two species are unclear. Compared with M. praecursor (illustrated by Cappetta, 2012, figure $207 \mathrm{~A}-\mathrm{P}$ ), M. nolfi (as figured in Zhelezko and Kozlov, 1999, pl. 28, figs. 3a, 3b, 4a, $4 b)$ has fully formed lateral cusplets.

Observations using high-resolution images of these cusplets of the holotype (no. KP OF 15478/ 41 DSM) and of the paratype (KP OF 15478/43 DSM) indicate that these cusplets are high and triangular. We also observed that the cusplets are positioned towards the margin in Macrorhizodus praecursor and are closer to the main cusp in $M$. nolfi. The root in $M$. nolfi is clearly higher than in the specimen of $M$. praecursor figured by Leriche (1906, pl. 16, figs. 12 and 12a), but similar to the specimen of $M$. praecursor figured by Cappetta (2012). Ignored for a long time, the existence of the sub-species $M$. praecursor americanus has been re-evaluated in recent decades and is mentioned only rarely in the literature. However, we consider the differences between $M$. praecursor and $M$. praecursor americanus to be too subtle and rather unclear. Cappetta (2012) regards M. praecursor americanus as valid and specific to Priabonian. We assign our specimens to Macrorhizodus praecursor due to the low development of the lateral heels and have decided not to assign the material to the sub-species level.

$$
\begin{gathered}
\text { Family MITSUKURINIDAE Jordan, } 1898 \\
\text { Genus STRIATOLAMIA Glikman, } 1964 \\
\text { Striatolamia macrota (Agassiz, 1843) } \\
\text { Figure 5.5-7', 10-11 }
\end{gathered}
$$

Material. Three anterior teeth (FES 068, 069, 070) and five lateral teeth (FES 058, 059, 067, 091, 103).

Description. The anterior teeth measure up to 46 $\mathrm{mm}$ apico-basally and up to $21 \mathrm{~mm}$ mesio-distally. The teeth are straight or trend slightly distally. The labial face is strongly convex in the lower third of 


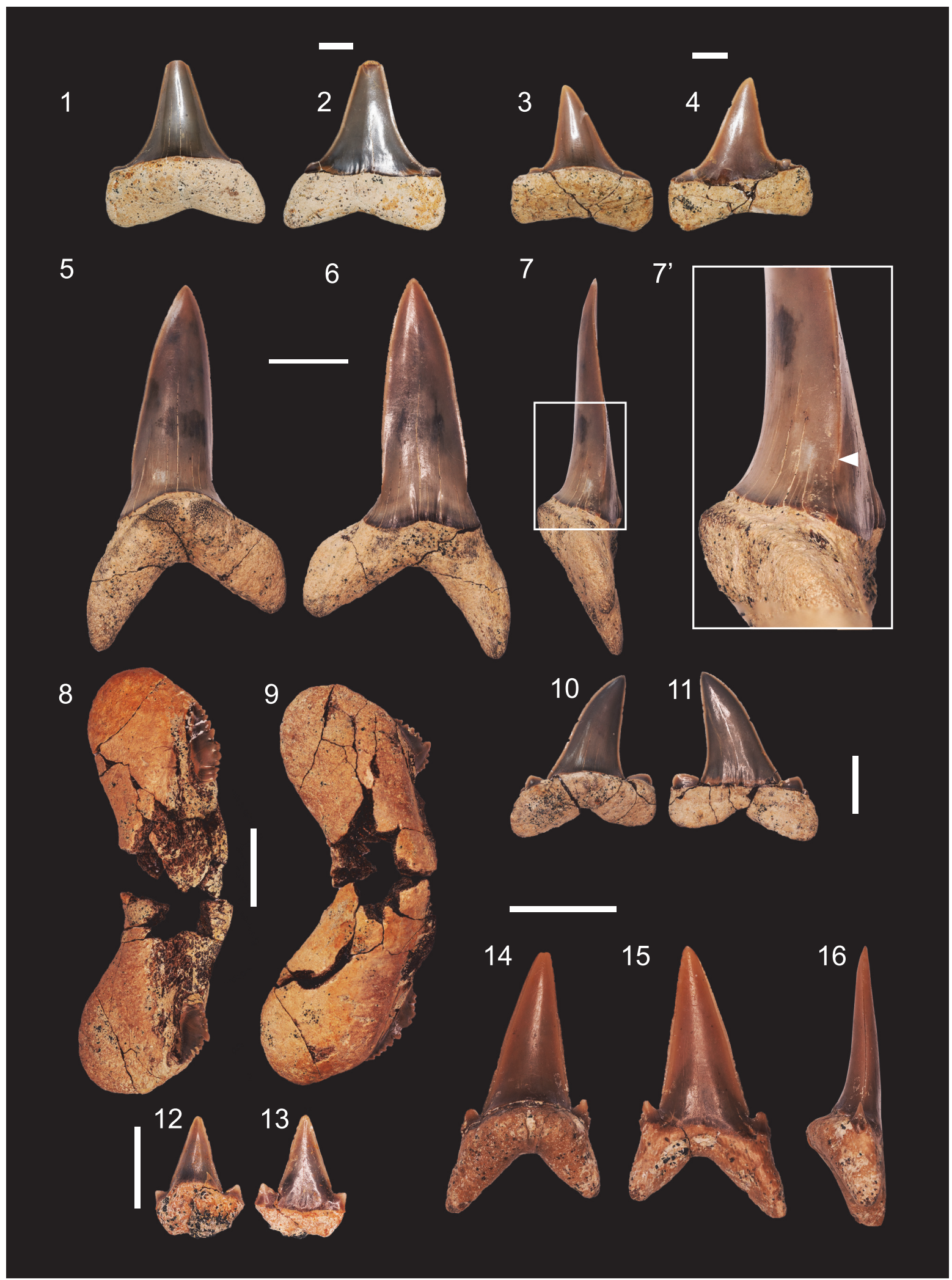

FIGURE 5. Fish fossils from Luna de Sus. 1-2, Macrorhizodus praecursor (FES 041). 3-4, (FES 042). 5-7', Striatolamia macrota (FES 068). 10-11, FES 067. 8-9, Otodus (Carcharocles) sp. (FES 071). 12-13, Abdounia sp. (FES 056). 14-16, Hypotodus verticalis (FES 061). 1, 3, 5, 9, 10, 12 , 14 lingual views. 2, 4, 6, 8, 11, 13, 15, labial views. 6, 16, distal views. $7^{\prime}$ detail of the cutting edge. Scale bars equal $5 \mathrm{~mm}(1-4,12,13)$ and $10 \mathrm{~mm}(5-11,14-16)$. 
the tooth, while the upper two thirds is flat. The lingual side is strongly convex and has faint vertical striations mostly in the lower half of the crown. The cutting edges are sharp and continuous but do not reach the base of the crown. One pair of very short but sharp lateral cusplets is present in two of the teeth. The cusplets do not reach the crown and are more pronounced on the labial side. The root lobes are long and pointed, with the exception of one specimen, whose distal lobe is more flattened. The lingual furrow is barely visible.

The lateral teeth have a main cusp with a distal inclination. The mesial edge is slightly convex in the upper third and has a distal cutting edge that is slightly concave in the lower third. The lingual face of the crown is flat and smooth while the labial face is slightly convex. The lingual face is ornamented with very weak, parallel striations. These striations extend only as far as the middle part of the crown in the apical-basal direction. In some specimens the striations are completely absent. The root lobes are rounded with the mesial lobe being the longest. The cusplets are well differentiated from the main cusp and have a rounded-triangular shape.

Remarks. Two species of Striatolamia are known, S. striata Winkler, 1876 and S. macrota Agassiz, 1843. S. striata is known only from the Paleocene (Müller, 1992; Dutheil, 1992; Smith et al., 1999; Moreau and Mathis, 2000), and it appears restricted to this age (Cappetta, 2012). Striatolamia macrota is very common in Ypresian, Lutetian (Cappetta, 2012) and Bartonian (Zhelezko and Kozlov, 1999). The characters we described and the geological age clearly indicate that these teeth are from Striatolamia macrota. The same features, including the faint striations of the adult specimens, have been reported by Zhelezko and Kozlov (1999) and Cunningham (2000).

Family OTODONTIDAE Glickman, 1964 |Genus OTODUS Agassiz 1843 (sensu Cappetta, 2012)

Otodus (Carcharocles) sp.

Figure 5.8-9

Material. One fragmented tooth (FES 071).

Description. The root measures $51 \mathrm{~mm}$ wide and both lobes are rounded. A single strong, wide and unevenly serrated cusplet is present on either side of the central cusp.

Remarks. The morphology agrees with that of Otodus (Carcharocles) auriculatus, a large shark from the middle Eocene, but the species could not be positively determined due to the lack of a main cusp.
Family ODONTASPIDIDAE Müller and Henle, 1839

Genus HYPOTODUS Jaekel, 1895

Hypotodus verticalis Agassiz, 1843

Figure 5.14-16

Material. One tooth (FES 061).

Description. The tooth has a triangular cusp with a broad base and smooth labial and lingual sides. The lingual side is convex, while the labial one is flat and has a medial vertical ridge. In distal view the crown is almost straight. Only one pair of cusplets is present on the sides of the crown from which they are separated by a rounded notch. The root lobes are moderately long and have pointed ends. The distal lobe is shorter than the mesial one. The lingual protuberance of the root is sharply outlined and bears a central, pronounced furrow.

Remarks. Although somewhat similar in general morphology, Hypotodus clearly differs from Jaekelotodus by lacking the enameloid that covers the upper part of the root lobes. Also, the labial side of Hypotodus is convex to a certain extent, while the labial side of Jaekelotodus is flat and has a clear basal depression.

The validity of this genus has been widely disputed. Over the years, authors such as Casier (1946), Gurr (1962), Herman (1977) and Ward (1988) misleadingly illustrated teeth belonging to other taxa but which they attributed to Hypotodus. Their opinions often changed the allocation of its sole species $H$. verticalis, from Hypotodus to other genera, hence invalidating the genus. Hypotodus has since been re-considered as valid, as enough characters have been found, and this made it possible to distinguish it from other genera (for further discussion on this subject see Cappetta and Nolf, 2005, p. 244-246).

Genus JAEKELOTODUS Menner, 1928
Jaekelotodus robustus (Leriche, 1921)

Figure 6.1-13

Material. Three anterior teeth (FES 062, 063, 064) and two lateral teeth (FES 060, 093).

Description. The teeth have a well-developed triangular crown that is slightly inclined distally. Both faces of the crown are smooth. The lingual face is strongly convex while the labial one is flat. At the base of the labial face is a central depression. On this same side the enameloid descends from the central depression and covers the upper portions of the root lobes. On the lingual side, the contact between the crown and the root is marked by a well defined neck. The sharp cutting edge reaches the base. A sharp cusplet occurs on either side of the 




FIGURE 6. Fish fossils from Luna de Sus. 1-3, Jaekelotodus robustus (FES 063). 4-8, (FES 065). 9-10, (FES 093). 1113, (FES 060). 1, 4, 9, 11, lingual views; 2, 5, 10, 12, labial views. 7, basal view. 8, apical view. 13, distal view. Scale bars equal $10 \mathrm{~mm}(1-8)$ and $5 \mathrm{~mm}(9-13)$. 
crown and each cusplet is inclined towards the main cusp. In the mesial or distal view it is observed that the cusplets are not following the same plan as the main cutting edge, but instead are lingually inclined. In specimen FES 063 it is observed the tendency towards the formation of a secondary pair of cusplets partially separated from the main pair. This tendancy is also observed for the mesial cusplet of FES 093.

Remarks. At least two Eocene species of Jaekelotodus are known, J. trigonalis and J. robustus. However, Cappetta (2012) lists also J. londonensis Zhelezko, 1994 and an impressive number of subspecies for $J$. trigonalis, all from Kazakhstan.

Teeth of Jaekelotodus are easily distinguished from those of other genera of the same age by the stout triangular crown with the central labial depression and the medium sized, hook-shaped cusplets. The teeth of $J$. robustus can be recognized based on their single pair of lateral cusplets that are shorter compared to J. trigonalis and $\mathrm{J}$. Iondonensis. Also, the root of $J$. robustus teeth has a furrow that is more pronounced than that of $\mathrm{J}$. trigonalis (Cappetta and Nolf, 2005).

Superorder BATOMORPHII Cappetta, 1980

Order MYLIOBATIFORMES Compagno, 1973

Superfamily MILIOBATOIDEA Compagno, 1973

Family MYLIOBATIDAE Bonaparte, 1838

Subfamily MYLIOBATINAE Bonaparte, 1835

Genus MYLIOBATIS Cuvier, 1816 cf. Myliobatis sp.

Figure 7.1-3

Material. One almost complete dental plate (FES 074).

Description. The specimen measures $32.1 \mathrm{~mm}$ labial-lingualy and has a maximum width of $29 \mathrm{~mm}$. The width-to-length ratio of the medial teeth is 5.3:1, while for the lateral ones it is $0.8: 1$ for the inner row and $0.6: 1$ for the outer row. A slight curvature is present in the labio-lingual direction. The eight medial teeth are the widest teeth in the plate and are slightly arched in occlusal view. All the teeth are hexagonal. The medial teeth are framed by two lateral roaws on each side. Longitudinal striations occur on the occlusal surface. The root is partially filled with sediment but is no more than 2 $\mathrm{mm}$ high and of a polyaulacorhize type. The root laminae are irregularly shaped, and the grooves between them are wider than the laminae.

Remarks. The genus is described by Bigelow and Schroeder (1948) and Cappetta (2012) as having a dental plate consisting of seven rows of teeth, the medial file being the widest, and each tooth being hexagonal shaped.
The number of fossil Myliobatis species is amazingly high. For instance, there are forty-five species described for the Eocene (Hovestadt and Hovestadt-Euler, 2013). However, Cappetta (1987) listed only six valid species from the entire Paleocene and later reduced this number to only five (Cappetta, 2012). We note that an extensive comparative study by Hovestadt and Hovestadt-Euler (2013) of the dental morphology of the extant representatives of the Myliobatinae subfamily showed that teeth morphological variation is very high even within the same species. For example, several species of Myliobatis show variation in the number of rows and in the width/length ratios. Also there is strong evidence that tooth morphology is correlated with dietary preference or prey availability within a given species (Hovestadt and HovestadtEuler, 2013, p. 22). As the specimen only partially fulfills the genus diagnostic characters, we assigned the specimen to cf. Myliobatis sp.

Family AETOBATIDAE Agassiz, 1958

Genus AETOBATUS Blainville, 1816 cf. Aetobatus sp.

Figure 7.4-7

Material. Two fragmentary upper teeth (FES 072, 073).

Description. The teeth are medium-sized $(37 \mathrm{~mm}$ width and $9 \mathrm{~mm}$ length for the figured specimen), laterally arched and with a wavy outline, smooth occlusal surface and roots divided longitudinally by ridges and grooves, which continue from underside towards backside.

Remarks. The antero-posterior arched, wavy or Mshaped teeth from the Myliobatinae that have a posterior displaced root are typically assigned to Aetobatus. As with the genus Myliobatis, the lack of data regarding the variability of tooth morphology in extant genera and the poor knowledge of genera such as Aetomylaeus led to erroneous assignations.

\section{Myliobatinae indet. 1 \\ Figure 7.8-12}

Material. One fragmented dental plate (VT459 BBUPSM).

Description. The fragment measures $28 \mathrm{~mm}$ labial-lingually and has a maximum width of 46 $\mathrm{mm}$. Only a single tooth is complete. The width:length ratio of the complete medial teeth is $5: 1$. Only a small fragment of a lateral tooth is present. The root is heavily worn and the laminae are razed. Interestingly, the root contains deep grooves between the teeth. 


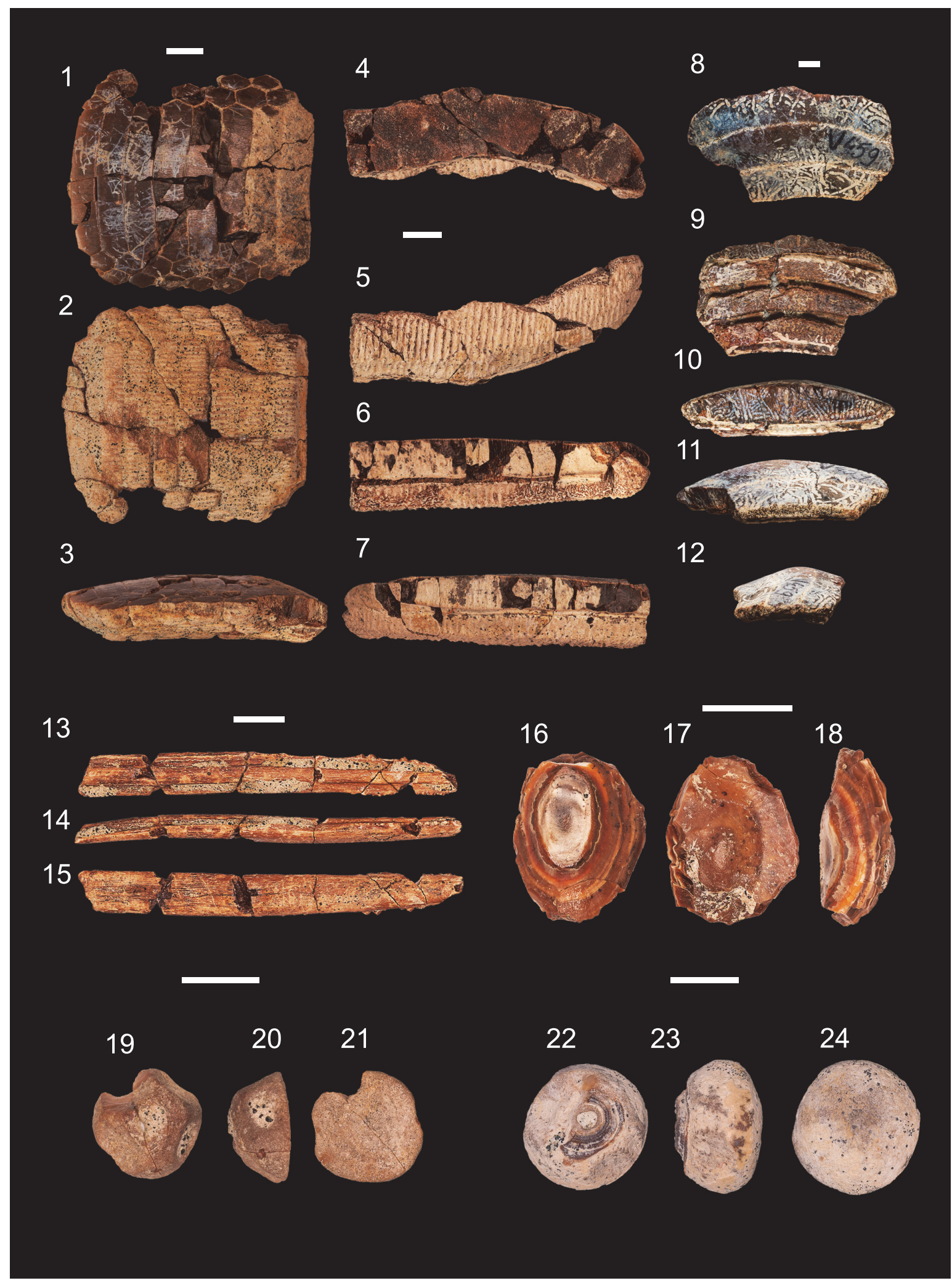

FIGURE 7. Fish fossils from Luna de Sus. 1-3, cf. Myliobatis sp. (FES 074). 4-7, cf. Aetobatus sp. (FES 072). 9-10, FES 093. 8-12, Myliobatinae indet. (1 VT 459). 13-15, Myliobatinae indet. 2 (FES 048). 16-18, Rajidae indet. (FES 046). 19-21, Batomorphii indet. (FES 086). 22-24, (FES 087). 6, 11, lingual views. 7, 10, labial views. 2, 5, 9, 13, 17, 21, 24, basal views. $1,4,8,15,16,19,22$, occlusal views. 3, 12, 14, 18, 20, 23, lateral views. Scale bars equal $5 \mathrm{~mm}$. 
Remarks. Similar deep grooves are present on a fragment assigned by Dica (2006) to Myliobatis sp. 1 ; this fragment was from the same formation, but a different locality (Căpușul Mic).

Myliobatinae indet. 2

Figure 7.13-15

Material. One tail sting (FES 048).

Description. The specimen is a fragment of a tail sting. The dorsal side is smooth. The ventral side has a longitudinal ridge along its entire length. The distal quarter of the sting exposes serrations on both sides. The exact shape of these serrations could not be determined due to the poor state of preservation.

Remarks. Since the tail stings of rays lack diagnostic characteristics according to Hovestadt and Hovestadt-Euler (2013), it could not be determined below the subfamily level.

Superfamily DASYATOIDEA Whitley, 1940

Family DASYATIDAE Jordan, 1888

Genus DASYATIS Rafinesque, 1810

Dasyatis cf. jaekeli (Leriche, 1905)

Figure 8.1-4

Material. One tooth (FES 095).

Description. The tooth is $1.8 \mathrm{~mm}$ wide and 1.4 $\mathrm{mm}$ high. Both occlusal and labial surfaces are covered by a network of alveoli and crests, while the lingual face is smooth. The tooth is deeply worn in the mesial direction of the occlusal face. The general shape of the occlusal surface is hexagonal. On lateral profile, one can notice a depression of the lingual side. The root is short and it has two lobes with triangular ends. The central foramen is barely visible between the root lobes.

Remarks. Tooth morphology of the genus is highly variable, and it is complicated by the gynatric heterodonty, as breeding males have cuspidate teeth and non-breeding males and all females have rounded ones (Kajiura and Tricas, 1996; Cappetta, 2012). The above described characters likely indicate a female tooth or a non-breeding male belonging to Dasyatis. It differs slightly from $D$. jaekeli, based on illustrations and descriptions from Leriche, (1905), Case (1994) and Ciobanu (2002), as it has a shallower lingual depression and the central occlusal ridge is less obvious. For this reason we treat the specimen here in an open nomenclature.

Order RHINOPRISTIFORMES Naylor et al., 2012

Family RHINOBATIDAE Müller and Henle, 1838 Genus RHINOBATOS Linck, 1790

Rhinobatos cf. steurbauti Cappetta and Nolf, 1981 Figure 8.5-8
Material. Two teeth (FES 096, 097).

Description. The teeth are very small. The widest crown measures $1.3 \mathrm{~mm}$. The teeth have a general globular shape with a very weakly marked transversal ridge on the occlusal surface. A central, elongated uvula is visible lingually. A pair of lateral uvulae is present on the sides of the central uvula. The lateral uvulae are shorter than the central one and do not diverge. All uvulae have a rounded basal end. The root is missing in both teeth.

Remarks. Two species of Rhinobatos are known from the Eocene: $R$. bruxelliensis Jaekel, 1894 and $R$. steurbauti Cappetta and Nolf, 1981. Rhinobatos bruxelliensis has pointed and more divergent uvulae while $R$. steurbauti has uvulae that are rounded and less or non-divergent (Cappetta and Nolf, 1981 , p. 96). Based on these differences, we assign the specimens to $R$. cf. steurbauti. Rhinobatos steurbauti is rarely reported but is present in the middle Eocene of France (Cappetta and Nolf, 1981), England (Bone et al., 1991) and Uzbekistan (Case et al., 1996).

\section{Family PRISTIDAE Bonaparte, 1838 Genus PRISTIS Linck, 1790 Pristis sp. \\ Figure 8.9-13}

Material. One incomplete rostral spine (FES 003). Description. The rostral spine measures $48.0 \mathrm{~mm}$ in apical-basal direction, $12.0 \mathrm{~mm}$ in anterior-posterior direction and 4 to $6 \mathrm{~mm}$ dorsal-ventrally. The spine is dorso-ventrally compressed with a rounded anterior margin, and with a shallow longitudinal groove along the posterior margin. Both apical and basal ends of the spine are broken. The apical surface has asymmetrical margins along the longitudinal groove.

Remarks. Similar to the Myliobatidae, numerous of fossil pristids have been described in the last few centuries. Many of these species were described from isolated rostral spines. Twenty-six species belonging to four genera (Propristis Dames, 1883; Mesopristis Farres, 2003; Pristis Linck, 1790; and Anoxypristis White and Moy-Thomas, 1941) have been described from the Eocene. Propristis has a unique morphology, with rostral spines nearly as long as high (Cappetta 2012, p. 396). The newest genus, Mesopristis, was set in synonymy with Anoxypristis by Cappetta (2012), but without explanation. However, the rostral spines of Mesopristis lack a posterior groove. Anoxypristis can be excluded for the same reason. Pristis is the only genus that has a posterior longitudinal groove. Within the respective genus there are numerous Eocene species but the species cannot be deter- 


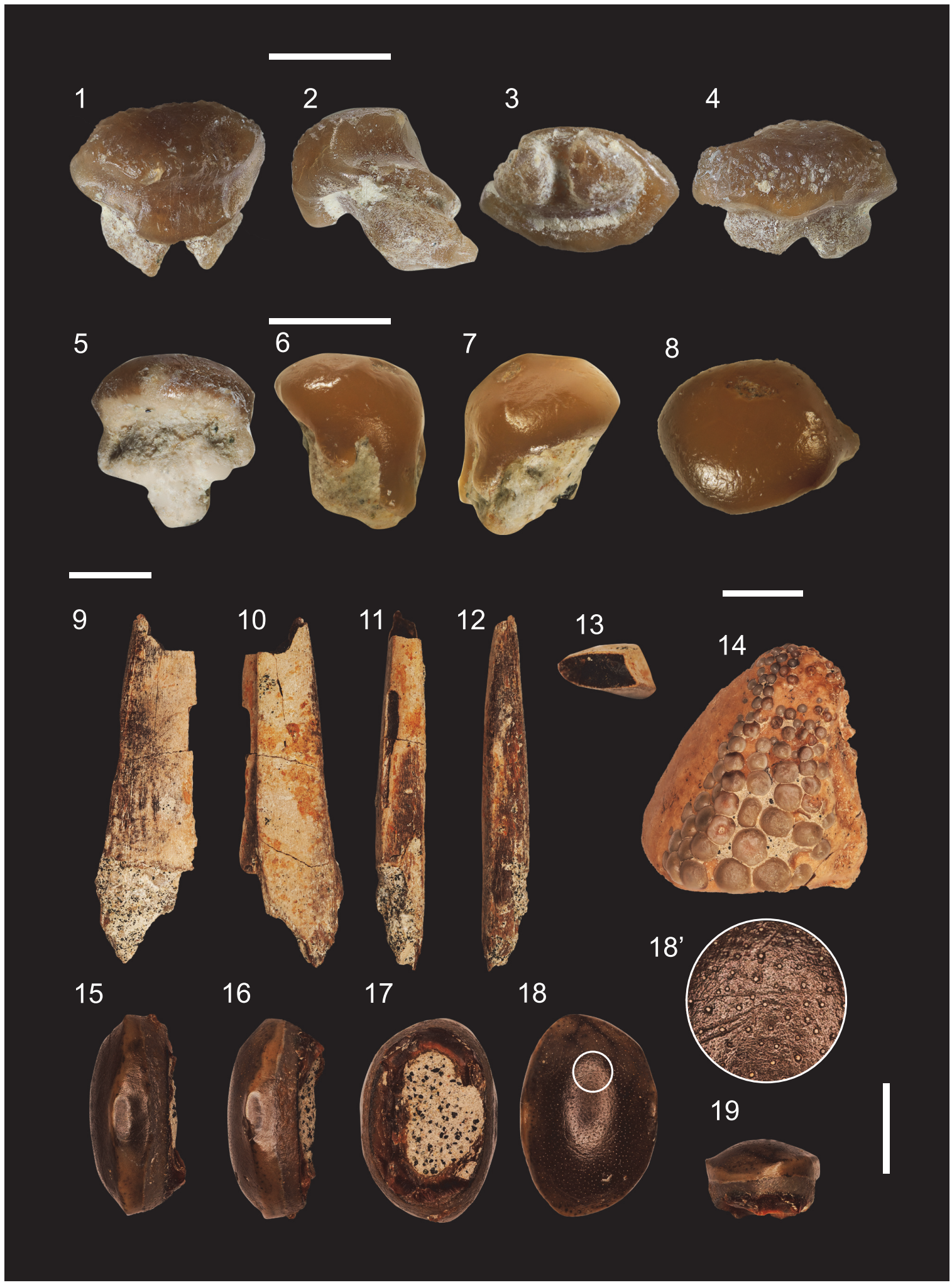

FIGURE 8. Fish fossils from Luna de Sus. 1-4, Dasyatis cf. jaekeli (FES 095). 5-8, Rhinobatos cf. steurbauti (FES 096). 9-13, Pristis sp. (FES 003). 14, Labridae indet. (FES 057). 15-19, Phacodus cf. punctatus (FES 012-040). 1, 5, 15, labial views. 4, 16, lingual views; 8, 14, 18, occlusal view. 9, dorsal view. 10, ventral view. 11, posterior view. 12, anterior view. 13, apical view. 2, 6, 7, 19, lateral views. 18', detail of the occlusal surface. Scale bars equal $1 \mathrm{~mm}(1-8)$, $5 \mathrm{~mm}(14-19)$ and $10 \mathrm{~mm}(9-13)$. 
mined from the material at hand. Observation on extant material belonging to Pristis, made by one of us (NT), indicate a high degree of variability in rostral spine length along with the width and depth of the posterior groove on the same specimen. Considering the above-mentioned facts the specimen, can be assigned with confidence to Pristis sp.

\section{Order cf. RAJIFORMES Berg, 1940 \\ Family, genus et species indet.}

Figure 7.16-18

Material. Two dermal spine bases (FES 046, 088). Description. These generally oval dermal spines have a truncated cone shape in lateral view. A shallow concavity and some very fine radial striations are present at the center of the dorsal side, as are some obvious concentric growth lines. The basal surface is slightly convex.

Remarks. The assignation of these thorn bases is challenging, as both Rajiformes and Myliobatiformes include numerous families where these dermal thorns are present (Deynat, 1998). Moreover, the local taphonomy may have reduced through abrasion some of the finer surface details. It is debatable if these thorns should be allocated to Rajiformes. Extant species show that thorn morphology can be variable on the same individual depending on the part of the body they occur (Gravendeel et al., 2002). Nevertheless, we found that several Rajidae genera have similarly shaped dermal denticles. In addition, we note that very similar fossil material from the upper Eocene of Germany has also been assigned to Rajiformes, based on comparison with extant material (Hillmer and Mundlos, 1981).

Superorder BATOMORPHII Cappetta, 1980 Batomorphii indet.

\section{Figure 7.19-24}

Material. Two dermal spine bases (FES 086, 087). Description. These two specimens differ greatly from the above-described material. Specimen FES 086 has a pentagonal outline in dorsal view and a truncated cone shape from a lateral view. A deep concavity is present at the center of the dorsal side. Striations and growth lines were absent, unlike the cf. Rajiformes specimens. The base is completely flat. Specimen FES 087 (Figure 7.2224) also differs from the cf. Rajiformes specimens and specimen FES 086 (Figure 7.19-21) by having a rounded outline and a torus-shaped lateral outline. The basal face is convex. This specimen has a concavity in the central raised portion of the dorsal surface.
Remarks. Specimen FES 087 is reminiscent of a pearl-shaped tubercle as defined by Deynat (1998, p.158).

Order PYCNODONTIFORMES Berg, 1940

Family incertae sedis

Genus PHACODUS Dixon, 1850

Phacodus cf. punctatus Dixon, 1850

Figure 8.15-19

Material. Twenty-nine teeth (FES 012 - 040).

Description. The teeth are generally oval or round and measure 4 to $11 \mathrm{~mm}$ along the long axis. The oral surface is covered by fine pits (Figure $8.18^{\prime}$ ) that penetrate the enamel deeply. The basal side of the crown has a deep oval-shaped depression. In some specimens, the edges of the teeth show differently-sized and geometrically-shaped protrusions (Figure 8.15-16, 8.19).

Remarks. The generally oval or round shape and the presence of the fine pits that cover the entire occlusal surface of the tooth are characteristic traits of the monotypic Phacodus punctatus. The presence of Phacodus in the Paleogene is unusual. Until recently, Phacodus was known only from the Cretaceous (Dixon, 1850; Santos and Figueiredo, 1988; Hooks et al., 2013). In Romania, a single occurrence of Phacodus after the K/T boundary was known only from specimens found a few years ago in the upper Eocene of Turnu Roşu (Ciobanu and Trif, 2014). A Phacodus tooth has also been found at Căpuşul Mic (Căpuş Fm.), but it was referred only as Pycnodontidae indet. (Dica, 2006, plate 15, figure 2).

The species is based on a fragmentary associated dentition (holotype NHM PV OR 25829), representing possibly a splenial fragment, found in the Cenomanian of the UK. For a long time the species and the genus were rejected, the holotype specimen being considered just a very worn and fragmentary pycnodont (Woodward, 1888, 1895). However, the genus and species were finally accepted as valid by Woodward (1909), who had previously rejected them. Since then the genus has been studied only rarely. Arambourg (1952) found a vomer and two fragmentary splenials in the Maastrichtian of Morocco (Ouled Abdoun). Based on this material, he erected a new variety, Phacodus punctatus var. africanus, due to a slight difference in the outline of the central teeth and in the smaller size of the lateral teeth. Santos and Figuiredo (1988) described Phacodus sergipensis almost three years later, from the Turonian of Brazil. The difference between this new species and $P$. punctatus, based mainly on two additional lateral rows, was rejected by other authors (e.g., Hooks et 
al., 2013) who argued that the variation of the lateral number of rows in pycnodonts had been noted in other species too. While we have assigned our Romanian teeth to Phacodus cf. punctatus, micromorphology and future research may lead us to a new conclusion.

\section{Order PERCIFORMES Bleeker, 1859 \\ Suborder LABROIDEI Bleeker, 1859 \\ Family LABRIDAE Cuvier, 1817 \\ Labridae indet. \\ Figure 8.14}

Material. One upper pharyngeal tooth plate (FES 057).

Description. A fragmented pharyngeal plate was collected having numerous rounded teeth with diameters of 0.25 to $2.5 \mathrm{~mm}$. The teeth are longest at the center of the plate and decrease towards the edges. The central teeth have a rough, irregular surface while the lateral ones have a completely smooth exterior. The teeth are arranged in regular, almost parallel rows. Together, they form a compact grinding surface. Note the considerable thickness of the plate in occlusal-basal direction, at 14.0 $\mathrm{mm}$. The plate is triangular in transversal section, including the grinding surface.

Remarks. Although some authors consider Labridae tooth plates non-diagnostic (e.g., Long, 1992), others, such as Dica (2002), consider the morphology and the arrangement of the teeth on the pharyngeal plates to be indicative characters on the genus level. An example of this is the lower pharyngeal plate of Lachnolaimus multidens from the Priabonian of Romania (Dica, 2002, fig. 3). The figured specimen compares well with the previously described lower pharyngeal plate of $L$. multidens from the Miocene of the Vienna Basin (Münster, 1846, figs. 5a-c). However, we consider that the assignment of other upper pharyngeal plates from Transylvania to species level, as $L$. multidens (Dica, 2002, pl. 1, fig. 4; Ciobanu, 2013, figs. 1-6) is only arbitrary as the lower plate is missing.

The assignment of our specimen to Labridae is however valid, based on similar fossil upper dentitions (Münster, 1846; Wainwright, 1987).

The Labridae family is known from Eocene, primarily from associated skeletons from Monte Bolca (Bannikov and Carnevale, 2010), but isolated pharyngeal triturating plates from Eocene Labridae have also been reported (Bellwood et al., 2019).

\section{DISCUSSION}

\section{Taxonomy}

The fish assemblage from Luna de Sus includes at least 17 species from as many genera; these fish belong to 12 families and seven orders. Seven of these genera (Physogaleus, Abdounia, Macrorhizodus, Striatolamia, Otodus, Jaekelotodus, Hypotodus) are extinct as is the entire order of Pycnodontiformes. One genus (Heterodontus) and four species (Galeocerdo cf. eaglesomei, Jaekelotodus robustus, Hypotodus verticalis and Rhinobatos cf. steurbauti) are new for Romania. This locality represents the second Cenozoic occurrence of the pycnodontiform Phacodus cf. punctatus in Romania and Europe. The first reported occurrence was the one from the upper Eocene of Turnu Roșu (Ciobanu and Trif, 2014). The Labridae material reported here represents the oldest record of this family in Romania.

\section{Taphonomy}

The relative abundance of teeth and dermal spines at this level puts it in contrast with other layers from the same locality. Only a single other layer contains fish teeth, namely the Nummulites perforatus lumachelle, from where a single fish tooth of Striatolamia macrota has been recovered.

The general state of preservation of the teeth is good, as evidenced by their sharp cutting edges, fine lateral cusplets and mostly intact roots. This mode of preservation indicates that the remains were transported only minimally before final burial; therefore, we consider the specimens to be autochthonous or parautochthonous. All the teeth have a reddish-brown color specific to the fossils of the iron oxide-rich Căpuș Formation (Stoicovici and Mureșan, 1964a, 1964b).

\section{Paleoecology}

The environment of sharks, rays and bony fishes from the locality of Luna de Sus can be reconstructed with some degree of approximation, considering the habitat preferences of extant relatives. Heterodontus is found in a wide range of depths, from intertidal to $275 \mathrm{~m}$ (Bass et al., 1975; Compagno, 2002). Rhizoprionodon is found both inshore and offshore, and at depths from less than $1 \mathrm{~m}$ to about $200 \mathrm{~m}$, with some species reaching $500 \mathrm{~m}$ depth (Compagno, 1984). A transition towards a shallower reef habitat has been encountered in some species (Sorenson et al., 2014). Galeocerdo inhabits a wide range of depths and habitats, from intertidal to over $200 \mathrm{~m}$ depth, but 
spends most of its time in less than $50 \mathrm{~m}$ of water (Compagno, 1984; Vaudo et al., 2014). Aetobatus is benthopelagic and typically occurs nearshore, in 1 to $60 \mathrm{~m}$ depth (Mundy, 2005; White and Last, 2016). Myliobatis is also benthopelagic and is confined mostly to warm waters and shallow depths to $80 \mathrm{~m}$ (Love et al., 2005; Ebert and Stehmann, 2013). Dasyatis is demersal (to $40 \mathrm{~m}$ depth), with most species preferring shallow water. Many Dasyatis species are found inshore, in lagoons and river-mouths (Struhsaker, 1969; Ebert and Stehmann, 2013). Rhinobatos lives in shallow inshore estuarine to marine waters, to $100 \mathrm{~m}$, but with some species living as deep as $180 \mathrm{~m}$ (Ebert and Stehmann, 2013). Extant Rhinobatidae live in warm-temperate to tropical waters, but a few species occur in deeper, cooler water offshore (Last and Compagno, 1999). Representatives of Pristis prefer shallow coastal waters and estuaries, typically in less than $10 \mathrm{~m}$ depth, but adults may be found in the $100 \mathrm{~m}$ depth or more (Poulakis and Seitz, 2004; Simpfendorfer, 2005; Ebert and Stehmann, 2013). Immature individuals are dependent on shallow habitats, living especially around the river-mouths (Simpfendorfer, 2005; Last et al., 2016b). Some extant Pristis species have a preference for freshwater habitats for nurseries (Peverell, 2005). The range for extant Pristidae is circumtropical (Nelson et al., 2016) and presumably the climate preference of the fossil Pristis was the same. Labrids are generally shallow-water fishes, though exceptionally, some species of Bodianus and Decodon occur in deep water at $200 \mathrm{~m}$ or more (Smith and Heemstra, 1986). Most Labridae live in association with structure such as coral reefs or rocky substrate in depths to $40 \mathrm{~m}$ (Allen et al., 2003).

The presence of Phacodus cf. punctatus in the Eocene of Luna is very unusual, as it is the only pycnodont found in northwestern Transylvania. Little is known about the ecological conditions of this fish. Taking into consideration the associated fauna from other Transylvanian occurrences (Ciobanu, 2002; Ciobanu and Trif, 2014), the warm, moderately deep waters are also among its environmental preferences. The pycnodonts are very rare in the northwestern portion of the Transylvanian Basin as compared to their occurrence in Turnu Roșu on the southern side of the basin. The pycnodont teeth are well represented in all three formations from Turnu Roșu (spanning the YpresianPriabonian interval). The presence of a high number of teeth from this single species in Luna de Sus indicates a well established population of pycnodonts in an unspecified ecological niche that allowed them to flourish among higher rank predators such as sharks.

The habitat preferences of modern relatives of studied fishes (Figure 9) indicate a moderate water depth of less than $200 \mathrm{~m}$ (more likely less than 100 $\mathrm{m}$, as inferred by the preferred depth) in a warm sea.

The knowledge of the middle Eocene fish (documented by teeth) is still limited on the regional level of Eastern Europe. We compared the occurrences of taxa from Luna de Sus with those from elsewhere in the region and with those from other better-known localities. For this comparison we only took into consideration the Chondrichthyes, given their numeric dominance at Luna de Sus. We assessed the faunal diversity at this site

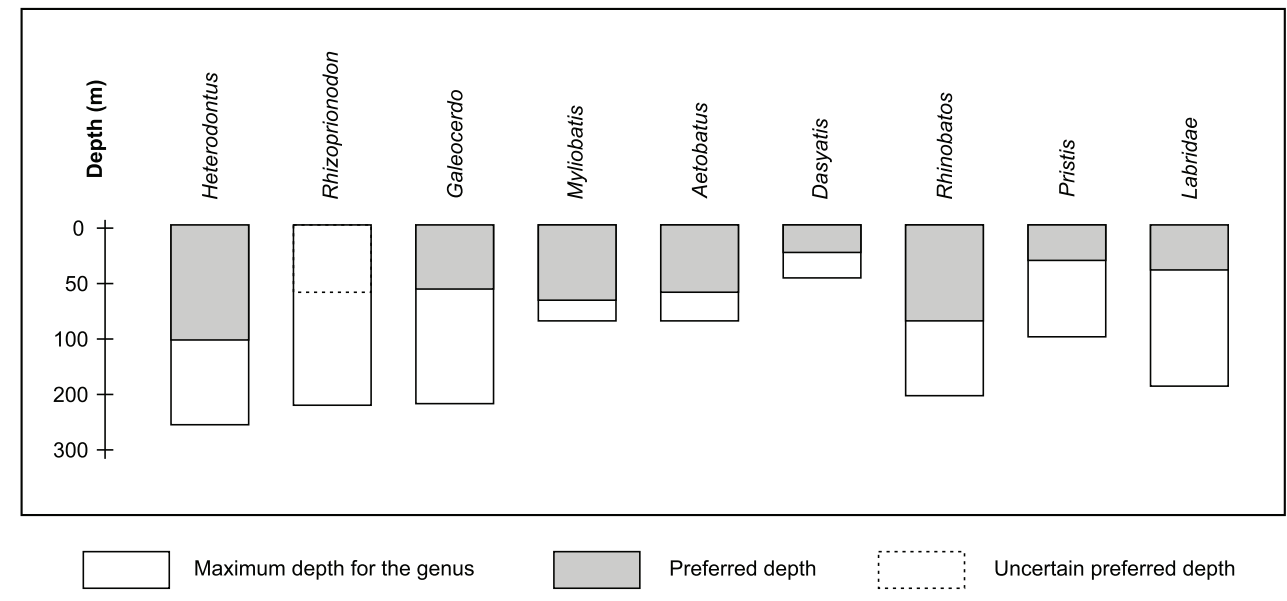

FIGURE 9. Depth range of extant equivalent taxa. 


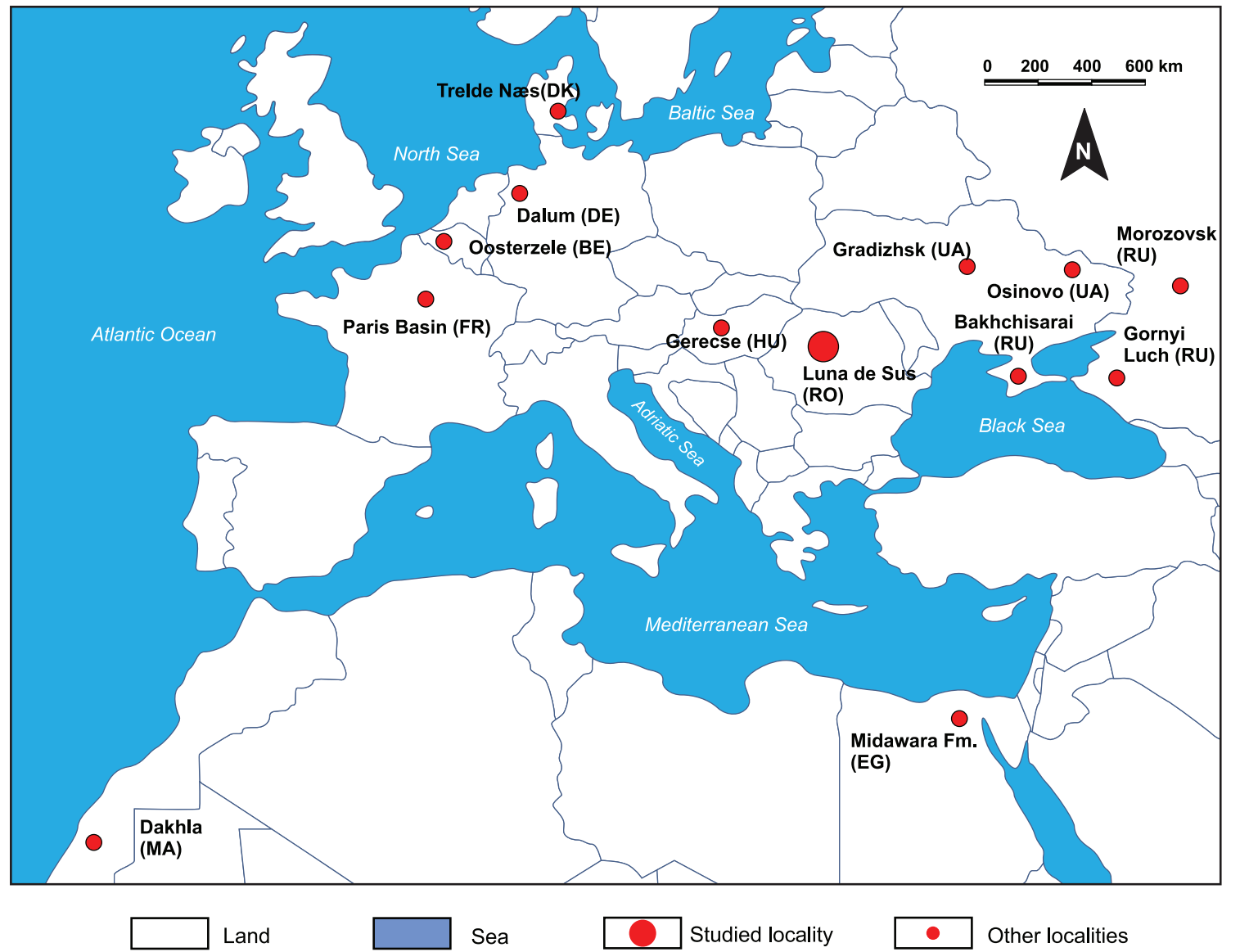

FIGURE 10. Map of central and eastern Europe with similar localities.

with that of 13 sites from the European part of Russia, Hungary, Ukraine, Denmark, Germany, Belgium, France, Egypt, and Morocco (Figure 10). The data covers the early Lutetian through the late Bartonian (Table 1).

We note a few genera that are probably more adaptable and migratory and which are common throughout the entire Tethys Sea and North-East Atlantic coast, such as Striatolamia, Macrorhizodus and the small Carcharhiniformes Abdounia and Physogaleus (Dutheil, 1990; Udovichenko, 2006; Eeckhaut and De Schutter, 2009; Udovichenko, 2009; Timircev and Popov, 2011; Diedrich, 2012). The absence of Otodus from many sites of the close-by region (Kocsis, 2002; Udovichenko, 2006; Udovichenko, 2009; Malyshkina et al., 2013; Leder, 2013) is surprising, considering that this predator is present in many localities of North-East Atlantic coast and North Africa (Dutheil, 1990; Eeckhaut and De Schutter, 2009; Adnet et al., 2010; Underwood et al., 2011; Diedrich, 2012; Carlsen and Cuny, 2014). It is good to note that diversity on the genus level in the North Sea Basin, Paris Basin and in the south of the Tethys Sea is significantly higher than in Eastern Europe. The presence of Pristidae and small Carcharhinidae in southwestern Morocco and in the Midawara Formation of Egypt (Adnet et al., 2010), where tropical conditions were well established, also indicates the existence of a warm habitat for Luna de Sus. Another evidence to support this hypothesis is the lack of deep, cold-water taxa such as Centrophorus, Chlamydoselachus, Coupatezia, Echinorhinus and Hexanchiformes that are present in other sites (Dutheil, 1990; Eeckhaut and De Schutter, 2009; Malyshkina et al., 2013; Carlsen and Cuny, 2014) that indicates a shallow depth and warmer conditions in Luna de Sus.

The climate reconstructions based on palynology (Petrescu and Balintoni, 2003) confirms a warm climate. This is supported further by reconstructions using oxygen and carbon isotopes measured on Nummulites perforatus collected at the same locality of Luna de Sus, on "Pavel Brook". For the interval involving the fish fauna, a mean paleotemperature is calculated at $26{ }^{\circ} \mathrm{C}$, while for the levels immediately above this interval a slightly 
TABLE 1. Orders and genera of Chondrichthyes documented in the Tethys Sea region. The numbers within brackets in the first row refer to localities: (1) Luna de Sus, Romania, lowermost Bartonian (this article); (2) Gradizhsk, Ukraine, Lutetian-Bartonian (Udovichenko, 2006); (3) Osinovo, Ukraine, lower Lutetian (Udovichenko, 2009); (4) Crimea, Russia, Gornyi Luch site, middle Eocene, most probably, Bartonian (Malyshkina et al., 2013); (5) Crimea, Russia, Bakhchisarai site, middle Eocene, most probably, Bartonian (Malyshkina et al., 2013; Leder, 2013); (6) Morozovsk, Russia, middle Eocene (Timircev and Popov, 2011); (7) Gerecse, Hungary, middle Eocene (Kocsis, 2002); (8) Trelde Næs, Denmark, upper Ypresian to middle Lutetian (Carlsen and Cuny, 2014); (9) Dalum and Osteroden, Germany (Diedrich, 2012); (10) Oosterzele, Lutetian, Belgium (Eeckhaut and De Schutter, 2009); (11) Paris Basin, the Lutetian-Bartonian interval only (Dutheil, 1990); (12) Midawara Fm., Egypt, Lutetian (Underwood et al., 2011); (13) Dakhla, Morocco (Adnet et al., 2010). $\left(^{*}\right)$ genera that are valid, but have an unclear/uncertain use in the Eocene; $\left({ }^{* *}\right)$ Otodus is used sensu Cappetta, (2012) and reunites Otodus and Carcharocles.

\begin{tabular}{|c|c|c|c|c|c|c|c|c|c|c|c|c|c|c|}
\hline Orders & Genera & 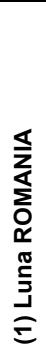 & 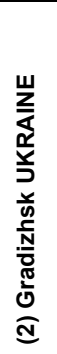 & 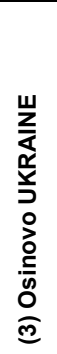 & 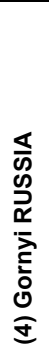 & 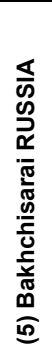 & 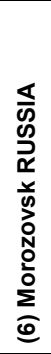 & 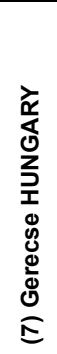 & 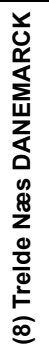 & 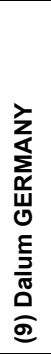 & 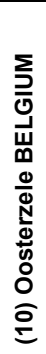 & 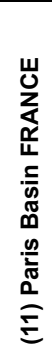 & 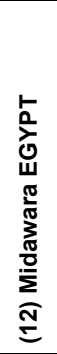 & 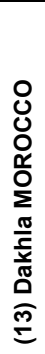 \\
\hline HETERODONTIFORMES & Heterodontus & - & - & - & & & - & & & & - & - & & \\
\hline \multirow[t]{7}{*}{ ORECTOLOBIFORMES } & Chiloscyllium & & & & & & & & & & & & - & - \\
\hline & Eostegostoma & & & & & & & & & & - & & - & \\
\hline & Hemiscyllium & & & & & & & & & & & & - & \\
\hline & Pararhincodon & & & & & & & & & & & & - & \\
\hline & Nebrius & & & & & & & - & & & - & - & - & - \\
\hline & Palaeorhincodon & & & & & & & & & & - & - & & \\
\hline & Protoginglymostoma & & & & & & & & & & - & & & \\
\hline \multirow[t]{20}{*}{ CARCHARHINIFORMES } & Abdounia & - & - & - & & - & - & & & & - & - & - & - \\
\hline & Carcharinus & & & & & & & & & & & & - & - \\
\hline & Crassescyliorhinus & & & & & & & & & & & & - & \\
\hline & Foumtizia & & & & & & & & - & & - & & & \\
\hline & Galeocerdo & - & & & & - & - & - & & - & - & - & - & - \\
\hline & Galeorhinus & & & - & & & & & & & - & - & & - \\
\hline & Hemipristis & & & & & & & & & & & & - & - \\
\hline & lago & & & & & & - & & & & & & - & - \\
\hline & Leptocharias & & & & & & & & & & & & - & \\
\hline & Megascyliorhinus & & & & & & & & - & & & & & \\
\hline & Misrichthys & & & & & & & & & & & & & - \\
\hline & Pachygaleus & & & & & & & & & - & - & & & \\
\hline & Paragaleus & & & & & & & & & & & & & - \\
\hline & Physogaleus & - & - & - & - & - & - & & - & & - & - & - & - \\
\hline & Premontreia & & & & & & & & & & - & & & \\
\hline & Rhizoprionodon & - & - & - & & & & & & & & - & - & - \\
\hline & Scyliorhinus & & & & & & & & & & - & - & & - \\
\hline & Sphyrna & & & & & & & & & & & & & - \\
\hline & Triakis & & & & & - & & & & & & & & - \\
\hline & Triakidae nov. genus & & & & & & & & & & & & - & \\
\hline
\end{tabular}


TABLE 1 (continued).

\begin{tabular}{|c|c|c|c|c|c|c|c|c|c|c|c|c|c|c|}
\hline Orders & Genera & 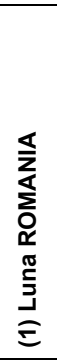 & 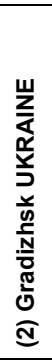 & 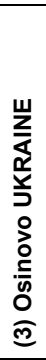 & 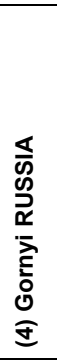 & 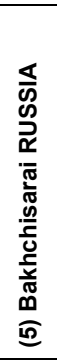 & 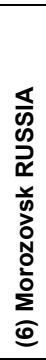 & 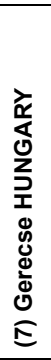 & 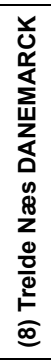 & 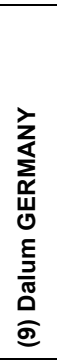 & 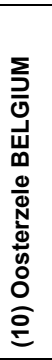 & 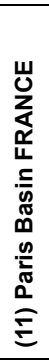 & 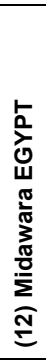 & 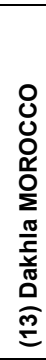 \\
\hline \multirow[t]{22}{*}{ LAMNIFORMES } & Alopias & & - & & - & - & & & - & & & & - & - \\
\hline & Anomotodon & & & & & & & & - & - & - & & & \\
\hline & Carcharias & & & & & & & & - & - & - & - & & - \\
\hline & Carcharodon * & & & & & & & & & - & & & & \\
\hline & Cretalamna & & & & & & & & - & & & & & - \\
\hline & Brachycarcharias & & & & & & - & & & - & - & & - & \\
\hline & Hypotodus & - & - & - & & & & & - & - & - & & & \\
\hline & Isurolamna & & - & - & - & - & & & - & - & - & - & & \\
\hline & Isurus * & & & & & & & & & - & & - & & \\
\hline & Jaekelotodus & - & - & - & & & - & & - & - & - & - & & \\
\hline & Macrorhizodus & - & - & - & - & & - & & - & - & - & & - & - \\
\hline & Mitsukurina & & & & & & & & - & & & & & \\
\hline & $\begin{array}{l}\text { Otodus sensu } \\
\text { Cappetta, } 2012\end{array}$ & - & & & - & & - & & - & - & - & - & - & - \\
\hline & Odontaspis & & - & - & & & - & & - & - & - & - & & \\
\hline & Palaeohypotodus & & & & & & & & - & & & & & \\
\hline & Parotodus & & & & & & & & & & & & - & \\
\hline & Sylvestrilamia & & & & & & & & & - & - & & & \\
\hline & Striatolamia & - & - & - & - & - & - & - & - & - & - & - & & \\
\hline & Turania & & & & & & & & - & & & & & \\
\hline & Usakias & & & & & & & & - & - & - & & & \\
\hline & Woellsteinia & & & & & & & & - & & & & & \\
\hline & Xiphodolamia & & & & & & & & - & - & - & & & - \\
\hline \multirow[t]{5}{*}{ HEXANCHIFORMES } & Chlamydoselachus & & & & & & & & - & & & & & \\
\hline & Heptranchias & & & & & & & & - & & & & & \\
\hline & Hexanchus & & - & & & & & & - & & - & & & \\
\hline & Notorhynchus & & - & & & & - & & - & & & & & \\
\hline & Weltonia & & & & & & & & - & & & & & \\
\hline SQUATINIFORMES & Squatina & & - & - & & & - & & - & & - & & & \\
\hline \multirow[t]{4}{*}{ SQUALIFORMES } & Centrophorus & & & & & & & & - & & & & & \\
\hline & Echinorhinus & & & & - & & & & - & & & & & \\
\hline & Isistius & & & - & & & - & & - & & - & & & \\
\hline & Squalus & & & & & & & & & & - & & & \\
\hline \multirow[t]{5}{*}{ MYLIOBATIFORMES } & Aetobatus & - & - & - & & & & - & & & - & - & - & - \\
\hline & Archaeomanta & & & & & & & & & & - & - & & - \\
\hline & Aturobatis & & & & & & & & & & & & & - \\
\hline & Burnhamia & & - & - & & - & & & & & - & - & & - \\
\hline & Coupatezia & & & & & & - & & - & & - & - & & \\
\hline
\end{tabular}


TABLE 1 (continued).

\begin{tabular}{|c|c|c|c|c|c|c|c|c|c|c|c|c|c|c|}
\hline Orders & Genera & 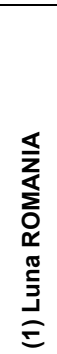 & 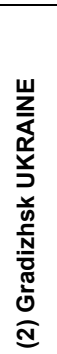 & 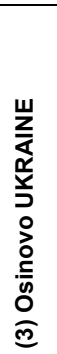 & 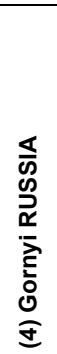 & 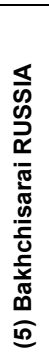 & 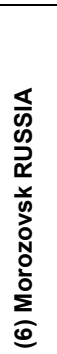 & 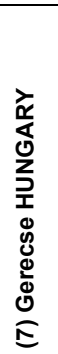 & 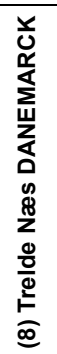 & 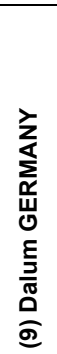 & 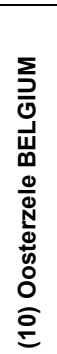 & 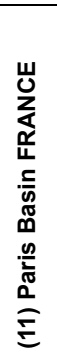 & 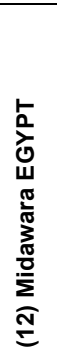 & 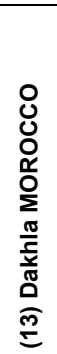 \\
\hline & Dasyatis & - & & & & & & - & - & & - & - & - & - \\
\hline & Garabatis & & & & & & & & & & & & & - \\
\hline & Gymnura & & & & & & & & & & - & & - & - \\
\hline & Heterotorpedo & & & & & & & & & & & - & & \\
\hline & Himantura * & & & & & & & & & & & & - & - \\
\hline & Hypolophodon & & & & & & & & & & & - & & \\
\hline & Jacquhermania & & & & & & & & & & & - & & \\
\hline & Leidybatis & & & & & & & & & & - & - & - & \\
\hline & Lophobatis & & - & & & & & & & & & & & \\
\hline & Mobula & & & & & & & & & & & & & - \\
\hline & Myliobatis & - & - & - & & & & - & & & - & - & - & - \\
\hline & Neotrygon & & & & & & & & & & & & - & \\
\hline & Pseudoaetobatus & & & & & & & & & & & - & & \\
\hline & Rhinoptera & & & & & & & & & & & & & - \\
\hline & Ouledia & & & & & & & & & & & & - & - \\
\hline & Taeniura & & & & & & & & & & & & - & \\
\hline \multirow[t]{7}{*}{ RHINOPRISTIFORMES } & Anoxypristis & & & & & & & & & & & - & - & - \\
\hline & Platyrhina & & & & & & & & & & & & - & \\
\hline & Platyrhinoidis & & & & & & & & & & & & - & \\
\hline & Pristis & - & & & & & & & & & - & - & - & - \\
\hline & Propristis & & & & & & & & & & & & - & - \\
\hline & Rhinobatos & - & & & & & - & - & & & - & - & & - \\
\hline & Rhynchobatus & & & & & & & & & & - & - & - & - \\
\hline PRISTIOPHORIFORMES & Pristiophorus & & & & & & & & - & & & & & \\
\hline TORPEDINIFORMES & Narcine & & & & & & & & & & & & - & - \\
\hline SELACHII INC. SEDIS & Odontorhytis & & & & & & & & & & & & - & - \\
\hline Total number of genera & & 15 & 18 & 17 & 7 & 9 & 15 & 7 & 32 & 17 & 41 & 33 & 36 & 38 \\
\hline Genera in common with Luna & & & 10 & 13 & 4 & 4 & 8 & 6 & 8 & 6 & 14 & 12 & 10 & 11 \\
\hline
\end{tabular}

cooler tendency was recorded, calculated at 23-24 ${ }^{\circ} \mathrm{C}$ (Bartholdy et al., 2000).

\section{CONCLUSIONS}

The richness of the middle Eocene fish fauna of the Luna de Sus in the northwestern portion of the Transylvanian Basin is significant, with at least 17 species belonging to as many (17) genera. The vast majority of the teeth found here belongs to Chondrichthyes and apparently originate from large-to-medium-sized fish, but this could be a consequence of the sampling bias. As revealed by the teeth taphonomy, the layer of sediments the teeth were recovered from most likely accumulated under low energy depositional conditions, and we therefore consider these fossils to be either autochthonous or parautochthonous. The faunal 
analysis of the northeast Atlantic coast and of the Tethys Sea reveals in part a common elasmobranch fauna with a variable number of common genera. These common genera are mostly lamniforms (Hypotodus, Jaekelotodus, Macrorhizodus, Otodus, Striatolamia) that were opportunistic predators of more open water or at least with broader habitat preferences.

Four species and one genus are reported here for the first time from the Eocene deposits of Romania. Aside from them, one of the most important occurrences in these deposits is Phacodus cf. punctatus. This second report in the northwestern
Transylvanian Basin confirms its survival of the $\mathrm{K} /$ Pg boundary.

\section{ACKNOWLEDGMENTS}

We thank both anonymous reviewers for their critical reading of the manuscript and for their valuable suggestions. The authors are very grateful to $J$. Seitz for not only reviewing the English language but also for the suggestions and references he sent. The authors also would like to thank A. Fuciu for the help in translation of the early version of the manuscript. The manuscript greatly benefited from the discussions with P. de Schutter and T. Malyshkina.

\section{REFERENCES}

Adnet, S., Cappetta, H., and Tabuce, R. 2010. A middle-late Eocene vertebrate fauna (marine fish and mammals) from southwestern Morocco; preliminary report: age and paleobiogeographical implications. Geological Magazine, 147(6):860-870. https://doi.org/ 10.1017/S0016756810000348

Agassiz, L., 1833-1843. Recherches sur les Poissons Fossiles (Contenant I'Histoire des Cycloides). Imprimerie de Petitpierre, Neuchatel. https://doi.org/10.5962/bhl.title.5748

Allen, G., Steene, R., Humann, P., and Deloach, N. 2003. Reef Fish Identification - Tropical Pacific. New World Publications Inc., Jacksonville.

Arambourg, C. 1952. Les vertébrés fossiles des gisements de phosphates (Maroc-AlgérieTunisie). Notes et Mémoires du Service Géologique du Maroc, 92:1-372.

Bass, A.J., D'Aubrey, J.D., and Kistnasamy, N. 1975. Sharks of the east coast of southern Africa. V. The families Hexanchidae, Chlamydoselachidae, Heterodontidae, Pristiophoridae, and Squatinidae. Investigational Report Oceanographic Research Institute, 43:1-50.

Bannikov, A.F. 2010. Iskopayemyye Pozvonochnyye Rossii i Sopredel'nykh stran. Iskopayemyye Kolyucheperyye Ryby (Teleostei, Acanthopterygii). GEOS, Moscow. (In Russian)

Bannikov, A.F. and Carnevale, G. 2010. Bellwoodilabrus landinii n. gen., n. sp., a new genus and species of labrid fish (Teleostei, Perciformes) from the Eocene of Monte Bolca. Geodiversitas, 32:201-220. https://doi.org/10.5252/g2010n2a2

Bartholdy J., Bellas, M.S., Keupp, H., Rusu, A., and Hosu, A. 2000. Oxygen and carbon isotope paleontology and paleoecological conditions in nummulitic banks: First results from the Transylvanian Eocene. GFF, 122:21-22.

Bellwood, D., Schultz, O., Siqueira, A.C., and Cowman, P.F. 2019. A review of the fossil record of the Labridae. Annalen des Naturhistorischen Museums Wien, 121:125-193.

Berg, L.S. 1937. A classification of fish-like vertebrates. Izvesttiya Akademii Nauk URSS, Biolgischeskaya, 4:1277-1280.

Berg, L.S. 1940. Sistema ryboobraznykh i ryb, nyne zhivushchikh i iskopaemykh. Trudy Zoologicheskogo Instituta Akademii Nauk URSS, 5:87-345. (In Russian)

Berg, L.S. 1958. System der Rezenten und Fossilen Fischartigen und Fische. Hochschulbücher für Biologie, Veb-Deutschen Verlag der Wissenschaften, Berlin.

Bigelow H.B. and Schroeder W.C. 1948. Fishes of the western North Atlantic. Memoir of Sears Foundation for Marine Research, 1:59-576. https://doi.org/10.5962/bhl.title.7464

Bleeker, P. 1859. Enumeratio specierum piscium hucusque in Archipelago indico observatarum. Acta Societatis Scientiarum Indo-Neerlandae, 6:1-276.

Blainville, H.M.D. 1816. Prodrome d'une nouvelle distribution systématique du règne animal. Bulletin des Sciences, par la Société Philomatique de Paris, 8:105-124.

Bonaparte, C.L. 1835. Iconografia della Fauna Italica per le Quattro Classi degli Animali Vertebrati. Tomo III. Pesci. Tipografia Salviucci, Roma. 
Bonaparte, C.L. 1838. Selachorum tabula analytica. Nuovi Annali della Science Naturali Bologna, 1:195-214.

Bone, D.A., Todd, J.A., and Tracey, S. 1991. Fossils from the Bracklesham Group exposed in the M27 Motorway excavations, Southampton, Hampshire. Tertiary Research, 12:131-137.

Bronn, H.G. 1831. Uebersicht der fossilen Ueberreste in den tertiären subapenninischen Gebirgen. Ergebnisse Meiner Naturhistorisch-ökonomischen Reise, 2:509-646.

Cappetta, H. 1980. Les sélaciens du Crétacé supérieur du Liban. II. Batoïdes. Palaeontographica, Abteilung A, 168:149-229.

Cappetta, H. 1987. Chondrichthyes II. Mesozoic and Cenozoic Elasmobranchii. Handbook of Paleoichthology. Volume 3B. Gustav Fischer Verlag, Stuttgart-New York.

Cappetta, H. 2012. Handbook of Paleoichthyology. Volume 3E: Chondrichthyes. Mesozoic and Cenozoic Elasmobranchii: Teeth. Verlag Dr. Friedrich Pfeil, München.

Cappetta, H. and Nolf, D. 1981. Les sélaciens de l'Auversien de Ronquerolles (Eocène supérieur du Bassin de Paris). Mededelingen Van De Werkgroep Voor Tertiaire En Kwartaire Geologie, 18:87-107.

Cappetta, H. and Nolf, D. 2005. Révision de quelques Odontaspididae (Neoselachii: Lamniformes) du Paléocène et de l'Eocène du Bassin de la Mer du Nord. Bulletin de l'Institut Royal des Sciences Naturelles de Belgique, Science de la Terre, 75:237-266.

Cappetta, H. and Traverse, M. 1988. Une riche faune de sélaciens dans le bassin à phosphate de Kpogamé-Hahotoé (Éocène moyen du Togo): Note préliminaire et précisions sur la structure et l'âge du gisement. Géobios, 21:359-365. https://doi.org/10.1016/s00166995(88)80058-5

Carlsen, A.W. and Cuny, G. 2014. A study of the sharks and rays from the Lillebaelt Clay (EarlyMiddle Eocene) of Denmark, and their palaeoecology. Bulletin of the Geological Society of Denmark, 62:9-88.

Case, G.R. 1981. Late Eocene selachians from South-central Georgia. Palaeontographica, Abteilung A, 176:52-79.

Case, G.R. 1994. Fossil fish remains from the late Paleocene Tuscahoma and early Eocene Bashi Formations of Meridian, Lauderdale County, Mississippi. Part I. Selachians. Palaeontographica, Abteilung A, 230:97-138.

Case, G.R. and Borodin, P. 2000. A middle Eocene selachian fauna from the Castle Hayne Limestone Formation of Duplin County, NC, Münchner Geowissenschaftliche Abhandlungen, 39:17-32.

Case, G.R. and Cappetta, H. 1990. The Eocene selachian fauna from the Fayum Depression in Egypt. Palaeontographica, Abteilung A, 212:1-30.

Case, G.R., Udovichenko, N.I., Nessov, L.A., Averianov, A.O., and Borodin, P.D. 1996. A middle Eocene selachian fauna from the White Mountain Formation of the Kizylkum Desert, Uzbekistan, C.I.S. Palaeontographica, Abteilung A, 242:99-126.

Casier, E. 1946. La faune ichthyologique de l'Ypresien de la Belgique. Memoires du Musee Royal d'Histoire Naturelle de Belgique, 104:1-267.

Casier, E. 1966. Faune Ichthyologique du London Clay. Trusters of the British Museum, London.

Ciobanu, R. 2002. Selacienii Paleogeni din România, Editura Universităţii Lucian Blaga, Sibiu.

Ciobanu, R. 2013. Labridae (Osteichthyes) from "Turnu Roşu (Romania) Eocene Limestone" Reserve. Brukenthal Acta Musei, 8:615-625.

Ciobanu, R. and Trif, N. 2014. The pycnodont Phacodus Dixon, 1850, in the late Eocene of the fossil area Turnu Roşu (Romania). Brukenthal Acta Musei, 9:587-600.

Codrea, V., Vremir, M., and Dica, P. 1997. Calcarul de Cluj de la Someş-Dig (Cluj-Napoca): semnificaţii paleoambientale şi impactul activităţilor antropice asupra aflorimentului. Complexul Muzeal Judeţean Bistriţa-Năsăud, Studii şi Cercetări, 3:31-39.

Compagno, L.J.V. 1973. Interrelationships of living elasmobranchs. Zoological Journal of the Linnean Society, 53(Supplement 1):15-61.

Compagno, L.J.V. 1977. Phyletic relationships of living sharks and rays. American Zoologist, 17(2):303-322.

Compagno, L.J.V. 1984. FAO Species Catalogue. Vol 4: Sharks of the world, Part 2 Carcharhiniformes. FAO Fisheries Synopsis, 4:251-633.

Compagno, L.J.V. 2002. FAO Species Catalogue. Vol 2: Sharks of the world, Bullhead, mackerel and carpet sharks (Heterodontiformes, Lamniformes and Orectolobiformes). FAO Species Catalogue for Fishery Purposes, 1:1-250. 
Cunningham, S.B. 2000. A comparison of isolated teeth of early Eocene Striatolamia macrota (Chondrichthyes, Lamniformes), with those of a recent sand shark, Carcharias taurus. Tertiary Research, 20:17-31.

Cuvier, G. 1816-1817. Le Règne Animal Distribué d'après son Organisation Pour Servir de Base à l'Histoire Naturelle des Animaux et d'Introduction à l'Anatomie Comparée. Les Reptiles, les Poissons, les Mollusques et les Annélides. Deterville, Paris. https://doi.org/10.5962/ bhl.title.130093

Dames, W. 1883. Über eine tertiäre Wirbelthierfauna von der westlichen Insel der Birket-El-Qrûn im Fajum (Aegypten). Sitzungsberichte der Königlich Preussischen Akademie der Wissenschaften zu Berlin, 6:129-153.

Deynat, P.P. 1998. Le revêtement cutané des raies (Chondrichthyes, Elasmobranchii, Batoidea). II. Morphologie et arrangement des tubercules cutanés. Annales des Sciences Naturelles, Zoologie et Biologie Animale, 19:155-172. https://doi.org/10.1016/s0003-4339(99)80004-5

Dica, P. 2002. A review of the Eocene diodontids and labrids from Transylvania. Studia Universitatis Babes-Bolyai, Geologia, 47:37-46.

Dica, P. 2006. Studii Paleoambientale în Formaţiunile Paleogene din NV-ul Depresiunii Transilvaniei pe Baza Asociaţiilor Ichtiologice. Unpublished Ph.D. Thesis, University BabeșBolyai, Cluj-Napoca, Romania.

Dica, P., Ciobanu, R., and Codrea, V. 1996. Some new batoids (Pisces, Chondrichthyes) from the Late Eocene (Priabonian) of the Cluj-Napoca area (Romania). Studia Universitatis Babeş-Bolyai, Geologia, 41:117-125.

Diedrich, C.G. 2012. Eocene (Lutetian) shark-rich coastal paleoenvironments of the southern North Sea Basin in Europe: biodiversity of the marine Fürstenau Formation including early white and megatooth sharks. International Journal of Oceanography, 2012: ID 565326. https://doi.org/10.1155/2012/565326

Dixon, E. 1850. Geology and Fossils of the Tertiary and Cretaceous Formations of Sussex. Longman, Brown, Green and Longmans, London. https://doi.org/10.5962/bhl.title.31159

Dutheil, D.B. 1992. Cycle sédimentaire et vertébrés d'une formation peu connue du Bassin de Paris, l'unité des Sables de Bourguillemont (Oise, France) (Paléocène supérieur). Geodiversitas, 24:753-764.

Dutheil, D.B. 1991. A checklist of Neoselachii (Pisces, Chondrichthyes) from the Palaeogene of the Paris Basin, France. Tertiary Research, 13(1):27-36.

Ebert, D.A. and Stehmann, M.F.W. 2013. Sharks, batoids and chimaeras of the North Atlantic. FAO Species Catalogue for Fishery Purposes 7:1-523.

Eckhaut, G. and De Schutter, P. 2009. The elasmobranch fauna of the Lede Sand Formation at Oosterzele (Lutetian, Middle Eocene of Belgium). Palaeofocus, 1:1-57.

Farrés, F. 2003. Mesopristis nov. gen. osonensis nov. sp., nuevo género y especie de pez-sierra del Eoceno de Vic, (Catalunya, NE. de España). Batalleria, 11:93-112.

Fuchs, H. 1963. Asupra prezentei genului Myliobatis in Eocenul Clujului, Studia Universitatis Babes-Bolyai, Geologie-Geografie, 1963:57-60.

Fuchs, H. 1966. Noi resturi de Myliobatis din Eocenul împrejurimilor Clujului. Studia Universitatis Babes-Bolyai, Geologie-Geografie, 1966:109-112.

Glikman, L.S. 1964. Akuly Paleogena i ikh Stratigraficheskoye Znacheniye. Nauka Press, Moscow. (In Russian)

González-Barba, G. 2003. Descripción de Asociaciones Faunísticas de Elasmobranquios Fósiles del Eoceno Superior (Priaboniano) de las Formaciones Tepetate y Bateque de Baja California Sur. Unpublished Ph.D. Thesis, Centro Interdisciplinario de Ciencias Marinas, La Paz, Mexico.

Gray, J.E. 1851. List of the Specimens of Fish in the Collection of the British Museum. Part I. Chondropterygii. British Museum (Natural History), London. https://doi.org/10.5962/ bhl.title.20819

Gravendeel, R., Van Neer, W., and Brinkhuizen, D. 2002. An identification key for dermal denticles of Rajidae from the North Sea. International Journal of Osteoarchaeology, 12:420441. https://doi.org/10.1002/oa.645

Gurr, P.R. 1962. A new fish fauna from the Woolwich Bottom Beds (Sparnacian) of Herne Bay, Kent. Proceedings of the Geological Association of London, 73:419-447. https://doi.org/ 10.1016/s0016-7878(62)80032-7 
Herman, J. 1977. Les sélaciens des terrains néocrétacés et paléocènes de Belgique et des contrées limitrophes. Eléments d'une biostratigraphie intercontinentale. Mémoires pour Servir à l'explication des Cartes Géologiques et Minières de la Belgique, 15:1-401.

Hillmer, G. and Mundlos, R. 1981. Hautzähne von Rochen (Fam. Rajidae) aus dem Eozän von Helmstedt (Niedersachsen, BRD). Neues Jahrbuch für Geologie und Paläontologie, 8:449462.

Hooks, G., Schwimmer, D., and Williams, D. 1999. Synonymy of the pycnodont Phacodus punctatus Dixon, 1850, and its occurrence in the Late Cretaceous of the southeastern United States. Journal of Vertebrate Paleontology, 19:588-590. https://doi.org/10.1080/ 02724634.1999.10011167

Hovestadt, D.C. and Hovestadt-Euler, M. 2013. Generic assessment and reallocation of Cenozoic myliobatins based on new information of tooth, tooth plate and caudal spine morphology of extant taxa. Paleontos, 20:1-65.

Huxley, T.H. 1880. On the application of the laws of evolution to the arrangement of the Vertebrata, and more particularly of the Mammalia. Proceedings of the Zoological Society, London 43:649-662.

Jaekel, O. 1895. Unter-tertiäre Selachier aus Südrussland. Mémoirs du Comité geologique de Saint Petersburg, 9:19-35.

Jordan, D.S. 1888. A Manual of the Vertebrate Animals of the Northern United States, Including the District North and East of the Ozark Mountains, South of the Laurentian Hills, North of the Southern Boundary of Virginia, and East of the Missouri River, Inclusive of Marine Species. A.C. McLurg and Company, Chicago. https://doi.org/10.5962/bhl.title.20990

Jordan, D.S. 1898. Description of a species of fish (Mitsukurina owstoni) from Japan, the type of a distinct family of lamnoid sharks. Proceedings of the California Academy of Sciences, 3(1):199-202.

Jordan, D.S. and Evermann, B.W. 1896. The fishes of North and Middle America: a descriptive catalogue of the species of fish-like vertebrates found in the waters of North America, north of the Isthmus of Panama. Part I. Bulletin of the United States National Museum, 47:1-1240. https://doi.org/10.5962/bhl.title.39714

Kajiura, S.M. and Tricas, T.C. 1996. Seasonal dynamics of dental sexual dimorphism in the Atlantic stingray Dasyatis sabina. The Journal of Experimental Biology, 199:2297-2306.

Klein, E.F. 1885. Beiträge zur Bildung des Schädels der Knochenfische. Jahreshefte Vereins Vaterlandischer Naturkunde in Würtenberg, 42:205-300.

Koch, A. 1894. Die Tertiärbildungen des Beckens der Siebenbürgischen Landestheile. I. Palaogene Abtheilung, Mittheilüngen aus dem Jahrbuche der Königlichen Ungarischen Geologischen Anstalt, 10:179-397.

Koch, A. 1900. Die Tertiarbildungen des Beckens der Siebenburgischen Landestheile. I. Neogene Abtheilung, Druck des Franklin-Verein, Budapest.

Kocsis, L. 2002. Vertebrate remains of the middle Eocene Csordakút basin, Hungary. Abstracts Volume and Excursions Field Guide, 7th European Workshop of Vertebrate Paleontology, Sibiu, p. 28.

Last, P.R. and Compagno, L.J.V. 1999. Dasyatidae, p.1479-1505. In Carpenter, K.E. and Niem, V.H. (eds.), FAO Species Identification Guide for Fishery Purposes. The Living Marine Resources of the Western Central Pacific, Batoid Fishes, Chimaeras and Bony Fishes Part 1 (Elopidae to Linophrynidae), vol. 3, Food and Agriculture Organization of the United Nations, Rome.

Last, P.R., De Carvalho, M.R., Corrigan, S., Naylor, G.J.P., Séret, B., and Yang, L. 2016a. The Rays of the World Project - an explanation of nomenclatural decisions, p.1-10. In Last, P.R. and Yearsley, G.K. (eds.), Rays of the World: Supplementary Information, CSIRO Special Publication, Melbourne.

Last, P.R., White, W.T., and Naylor, G.J.P. 2016b. Sawfishes, Family Pristidae, p.59-64. In Last, P.R., White, W.T., Carvalho, M.R. de, Séret, B., Stehmann, M.F.W., and Naylor, G.J.P. (eds.), Rays of the World. CSIRO Publishing, Melbourne.

Leder, R.M. 2013. Eocene Carcharinidae and Triakidae (Elasmobranchii) of Crimea and Kazakhstan. Leipziger Geowissenschaften, 20:1-57.

Leriche, M. 1905. Les poissons tertiaires de la Belgique. II. Les poissons éocènes. Mémoires du Musée Royal d'Histoire Naturelle de Belgique, 11:49-228. 
Leriche, M. 1921. Sur les restes de poissons remaniés dans le néogène de la Belgique. Leur signification au point de vue de l'histoire géologique de la Belgique pendant le Tertiaire supérieur. Bulletin de la Société belge de Géologie, 30:115-120.

Leriche, M. 1942. Contribution à l'étude des faunes ichthyologiques marines des terrains tertiaires de la Plaine Côtière Atlantique et du centre des Etats-Unis. Les synchronismes des formations tertiaires des deux côtés de l'Atlantique. Mémoires de la Société Géologique de France, 45:1-110.

Linck, H.F. 1790. Versuch einer Eintheilung der Fische nach den Zähnen. Magazin für das Neueste aus der Physik und Naturgeschichte, 6:28-38.

Long, D. J. 1992. An Eocene wrasse (Perciformes; Labridae) from Seymour Island. Antarctic Science, 4:235-237. https://doi.org/10.1017/s095410209200035x

Love S.M., Mecklenburg, C.W., Mecklenburg, T.A., and Thorsteinson, L.K. 2005. Resource Inventory of Marine and Estuarine Fishes of the West Coast and Alaska: A Checklist of North Pacific and Arctic Ocean Species from Baja California to the Alaska - Yukon Border. USGS Publications Warehouse, Santa Barbara.

Maisch, H.M., Becker, M.A., Raines, B.W., and Chamberlain, J.A. 2014. Chondrichthyans from the Lisbon-Tallahatta Formation Contact (Middle Eocene), Choctaw County, Silas, Alabama. Paludicola, 9:183-209.

Malyshkina, T.P., González-Barba, G., and Bannikov, A.F. 2013. Records of elasmobranchian teeth in the Bartonian of the northern Caucasus (Russia) and Crimea (Ukraine). Paleontological Journal, 47:98-103. https://doi.org/10.1134/s0031030113010085

Malyshkina, T.P. and Ward, D.J. 2016. The Turanian Basin in the Eocene: The new data on the fossil sharks and rays from the Kyzylkum Desert (Uzbekistan). Proceedings of the Zoological Institute of the Russian Academy of Sciences, 320:50-65.

Menner, V.V. 1928. Les selaciens du Paleogene de Manghyschlack, d'Emba et du versant oriental d'Oural. Bulletin of Moscow Society of Naturalists, Section Geology, 6:292-338. (In Russian)

Meulenkamp, J.E. and Sissingh, W. 2003. Tertiary palaeogeography and tectonostratigraphic evolution of the Northern and Southern Peri-Tethys platforms and the intermediate domains of the African-Eurasian convergent plate boundary zone. Palaeogeography, Palaeoclimatology, Palaeoecology, 196:209-228. https://doi.org/10.1016/S00310182(03)00319-5

Montfort, D.P. 1808. Conchyliologie Systématique, et Classification Méthodique de Coquilles. F. Schoell, Paris. https://doi.org/10.5962/bhl.title.10571

Moreau, F. and Mathis, S. 2000. Les élasmobranches du Thanétien (Paléocène) du nord de la France, des carrières de Templeuve et de Leforest. Cossmanniana, 7:1-18.

Mundy, B.C. 2005. Checklist of the fishes of the Hawaiian Archipelago. Bishop Museum Bulletin in Zoology, 6:1-704.

Müller, J. and Henle, F.G.J. 1838-1841. Systematische Beschreibung der Plagiostomen, Veit \& Co., Berlin.

Müller, A. 1992. Ichthyofaunen aus dem atlantischen Tertiär der USA. Leipziger Geowissenschaften, 9/10:1-360.

Münster, G.G. 1846. Ueber die in der Tertiär - Formation des Wiener Beckens vorkommeden Fisch - Ueberreste, mit Beschreibung einiger neuen merkwürdigen Arten, Beiträge zur Petrefacten Kunde, 7:1-31.

Naylor, G.J.P., Caira, J.N., Jensen, K., Rosana, K.A.M., Straube, N., and Lakner, C. 2012. Elasmobranch phylogeny: A mitochondrial estimate based on 595 species, p. 31-56. In Carrier, J.C., Musick, J.A., and Heithaus, M.R., (eds.), Biology of Sharks and Their Relatives, CRC Press, Boca Raton.

Neugeboren, J. L. 1850. Die vorweltlichen Squaliden-Zähne aus dem Grobkalke bei Portsesd am Altfluß unweit Talmats. Archiv des Vereins für Siebenbürgische Landeskunde, 2:1-44.

Neugeboren, J.L. 1851. Die vorweltlichen Squaliden-Zähne aus dem Grobkalke bei Portsesd am Altfluße unweit Talmats. Archiv des Vereins für Siebenbürgische Landeskunde, 3:151-213.

Noubhani, A. and Cappetta, H. 1997. Les Orectolobiformes, Carcharhiniformes et Myliobatiformes (Elasmobranchii, Neoselachii) des bassins à phosphate du Maroc. (Maastrichtien-Lutétien basal). Systématique, biostratigraphie, évolution et dynamique des faunes. Palaeo Ichthyologica, 8:1-327.

Pávay, A., 1871. Die geologischen Verhältnisse der Umgebung von Klausenburg. Mittheilüngen aus dem Jahrbuche der Königlichen Ungarischen Geologischen Anstalt, 16:344-346. 
Petrescu, I. and Balintoni, I. 2003. Paleoclimate and paleorelief in Romania during the Tertiary Period, Analele Științifice ale Universității Al. I. Cuza, lași, Geologie, 49/50:183-189.

Peverell, C.S. 2005. Distribution of sawfishes (Pristidae) in the Queensland Gulf of Carpentaria, Australia, with notes on sawfish ecology. Environmental Biology of Fishes, 73:391-402. https://doi.org/10.1007/s10641-005-1599-8

Popescu, B. 1978. On the lithostratigraphic nomenclature of the NW Transylvania Eocene. Revue Roumaine de Géologie, Géophysique, et de Géographie, Série Géologie, 22:99-107.

Poulakis, G.R. and Seitz, J. 2004. Recent occurrence of the smalltooth sawfish, Pristis pectinata (Elasmobranchiomorphii: Pristidae), in Florida Bay and the Florida Keys, with comments on sawfish ecology. Florida Scientist, 67:27-35.

Rafinesque, C.S. 1810. Caratteri di Alcuni Nuovi Generi e Nuove Specie di Animali e Pinate della Sicilia, con Varie Osservazioni Sopra i Medisimi, 1ère partie. Stampe din Sanfilippo, Palermo. https://doi.org/10.5962/bhl.title.104418

Rusu, A. 1987. Ostreina Biohorizons in the Eocene of the North-West Transylvania (Romania), p. 175-182. In Petrescu, I. and Ghergari, L. (eds.), The Eocene from the Transylvanian Basin, Romania. University of Cluj-Napoca, Cluj-Napoca.

Rusu, A., Brotea, D., and Melinte, M.C. 2004. Biostratigraphy of the Bartonian deposits from Gilău area (NW Transylvania, Romania). Acta Palaeontologica Romaniae, 4:441-454.

Santos, R.D.S. and De Figueiredo, F.J. 1988. Phacodus sergipensis sp. nov. (Pisces, Pycnodontiformes) do Cretaceo do Estado de Sergipe, Brazil. Anais da Academia Brasileira de Ciencias, 60:447-451.

Săndulescu, M., 1984. Geotectonica României, Editura Tehnică, Bucharest.

Simpfendorfer, C.A. 2005. Threatened fishes of the world: Pristis pectinata Latham, 1794 (Pristidae). Environmental Biology of Fishes, 73:20. https://doi.org/10.1007/s10641-0044174-9

Sorenson, L., Santini, F., and Alfaro, E. 2014. The effect of habitat on modern shark diversification, Journal of Evolutionary Biology, 27:1536-1548. https://doi.org/10.1111/ jeb.12405

Smith, M.M. and Heemstra, P.C. 1986. Smiths' Sea Fishes, Springer Verlag, Berlin-New York. https://doi.org/10.1007/978-3-642-82858-4

Smith, R., Smith, T., and Steurbaut, E. 1999. Les élasmobranches de la transition PaléocèneÉocène de Dormaal (Belgique): implications biostratigraphiques et paléobiogéographiques. Bulletin de Societé Géologique de France, 170:327-334.

Stoicovici, E. and Mureșan, I., 1964a. Studiul zăcământului de limonit oolitic și de glauconit din formațiunile eocene ale Bazinului Transilvaniei, I. Studia Universitatis Babeș-Bolyai Seria Geologie-Geografie, 1:7-16.

Stoicovici, E. and Mureșan, I. 1964b. Studiul zăcământului de limonit oolitic și de glauconit din formațiunile eocene ale Bazinului Transilvaniei, II. Studia Universitatis Babeș-Bolyai Seria Geologie-Geografie, 2:17-29.

Stromer, E. 1905. Die Fischreste des Mittleren und Oberen Eocäns von Ägypten. I. Teil: Die Selachier, A. Myliobatiden und Pristiden. Beiträge zur Paläontologie und Geologie Österreich-Ungarns, 18:163-185.

Struhsaker, P. 1969. Observations on the biology and distribution of the thorny stingray, Dasyatis centroura. Bulletin of Marine Science, 19:456-481.

Şuraru, M., Strusievici, R., and Laszlo, K. 1980. Resturile unor dinţi de teleostei în Eocenul de la Cluj-Napoca. Studii şi Cercetări Geologice-Geofizice-Geografice, 25:177-181.

Şuraru, N. and Şuraru, M. 1987. Neue angaben uber eininge fischreste aus dem Eozän des Transylvanischen beckens, p. 127-134. In Petrescu, I. and Ghergari, L. (eds.), The Eocene from the Transylvanian Basin, Romania. University of Cluj-Napoca, Cluj-Napoca.

Timirchev, F.K. and Popov, E.V. 2011. Khryashchevyye ryby v srednemeotsene Rostovskoy oblasti. Modern Paleontology: Classical and Newest Methods. Abstract Book. Borissiak Paleontological Institute of the Russian Academy of Sciences, Moscow (In Russian)

Udovichenko, N.I. 2006. Zuby Akul Iz Otlozheniy Kiyevskogo Regioyarusa Rayona Gradizhska, p. 201-208. In Gozhik, P.F. (ed.), Paleontological and Biostratigraphic Problems of the Proterozoic and Phanerozoic of Ukraine, The Institute of Geological Sciences of the National Academy of Sciences of Ukraine, Kiev. (In Russian with English abstract) 
Udovichenko, N.I. 2009. Ichthyofauna and age of the Paleogene sands of Osinovo area, Lugansk Region. Proceedings of the Institute of Geological Sciences of the National Academy of Sciences of Ukraine, Kiev, 255-261. (In Russian with English abstract)

Underwood, C.J., Ward, D.J., King, C., Antar, S.M., Zalmout, I.S., and Gingerich, P.D. 2011. Shark and ray faunas in the Middle and Late Eocene of the Fayum Area, Egypt. Proceedings of the Geologists' Association, 122:47-66.

Vaudo, J.J., Wetherbee, B.M., Harvey, G., Nemeth, R.S., Aming, C., Burnie, N., Howey-Jordan, L.A., and Shivji, M.S. 2014. Intraspecific variation in vertical habitat use by tiger sharks (Galeocerdo cuvier) in the western North Atlantic. Ecology and Evolution, 4:1768-1786. https://doi.org/10.1002/ece3.1053

Wainwright, P.C. 1987. Biomechanical limits to ecological performance: mollusk-crushing by the Caribbean hogfish, Lachnolaimus maximus (Labridae). Journal of Zoology, 213:283-297. https://doi.org/10.1111/j.1469-7998.1987.tb03704.x

Ward, D. J. 1988. Hypotodus verticalis (Agassiz, 1843), Hypotodus robustus (Leriche, 1921) and Hypotodus heinzelini (Casier, 1967), Chondrichthyes, Lamniformes, junior synonyms of Carcharias hopei (Agassiz, 1843). Tertiary Research, 10:1-12.

Westgate, J.W. 1989. Lower vertebrates from an estuarine facies of the middle Eocene Laredo Formation (Claiborne Group), Webb County, Texas. Journal of Vertebrate Paleontology, 9:282-294. https://doi.org/10.1080/02724634.1989.10011763

White, E.I. 1955. Notes on African Tertiary sharks. Bulletin of the Geological Survey of Nigeria, 5:319-325.

White, E.I. and Moy-Thomas, J.A. 1940. Notes on the nomenclature of fossil fishes. Part. I: Homonyms A-C. Annals and Magazine of Natural History, (11)5:502-507.

White, W.T. and Last, P.R. 2016. Pelagic eagle rays, Family Aetobatidae, p. 726-731. In Last, P.R., White, W.T., Carvalho, M.R. de, Séret, B., Stehmann, M.F.W, and Naylor, G.J.P. (eds.), Rays of the World. CSIRO Publishing, Melbourne.

Whitley, G.P. 1929. Additions to the check-list of the fishes of New South Wales. No. 2. Australian Zoologist, 5:353-357.

Whitley, G.P. 1940. The Fishes of Australia. Part 1. The Sharks, Rays, Devil Fishes and Other Primitive Fishes of Australia and New Zealand. Royal Zoological Society of New South Wales, Sydney.

Winkler, T.C. 1874. Mémoire sur des dents de poissons du terrain bruxellien. Archives du Musée Teyler, 3:295-304.

Winkler, T.C. 1876. Deuxième mémoire sur des dents de poissons fossiles du terrain bruxellien. Archives du Musée Teyler, 4:16-48.

Woodward, A.S. 1888. A synopsis of the vertebrate fossils of the English Chalk. Proceedings of the Geologists' Association, 10:273-338. https://doi.org/10.1016/s0016-7878(88)80065-8

Woodward, A.S. 1895. Catalogue of the Fossil Fishes in the British Museum (Natural History) Volume. 3, British Museum (Natural History), London. https://doi.org/10.5962/bhl.title.61854

Woodward, A.S. 1909. The fossil fishes of the English chalk. Part V. Monograph of the Palaeontographical Society London, 63:153-184.

Zhelezko, V.I. 1994. Sharks of family Jaekelotodontidae of European and middle Asian paleobiogeographic provinces. Bulletin Moscow Society of Naturalists, 69:47-62.

Zhelezko, V.I. and Kozlov, V.A. 1999. Elasmobrankhii I Biostratigrafiya Paleogena Zaural'ya I Sredney Azii. Russian Academy of Sciences, Urals Branch, Ekaterinburg. (In Russian with English abstract) 